Review

\title{
Postbiotic-Enabled Targeting of the Host-Microbiota-Pathogen Interface: Hints of Antibiotic Decline?
}

\author{
Matteo Puccetti ${ }^{\mathbb{D}}$, Styliani Xiroudaki, Maurizio Ricci ${ }^{\mathbb{D}}$ and Stefano Giovagnoli * $\mathbb{D}$ \\ Department of Pharmaceutical Sciences, via del Liceo 1, University of Perugia, 06123 Perugia, Italy; \\ matteo.puccetti@gmail.com (M.P.); styliani.xiroudaki@studenti.unipg.it (S.X.); maurizio.ricci@unipg.it (M.R.) \\ * Correspondence: stefano.giovagnoli@unipg.it; Tel.: +39-075-5585162
}

Received: 11 May 2020; Accepted: 1 July 2020; Published: 4 July 2020

check for updates

\begin{abstract}
Mismanagement of bacterial infection therapies has undermined the reliability and efficacy of antibiotic treatments, producing a profound crisis of the antibiotic drug market. It is by now clear that tackling deadly infections demands novel strategies not only based on the mere toxicity of anti-infective compounds. Host-directed therapies have been the first example as novel treatments with alternate success. Nevertheless, recent advances in the human microbiome research have provided evidence that compounds produced by the microbial metabolism, namely postbiotics, can have significant impact on human health. Such compounds target the host-microbe-pathogen interface rescuing biotic and immune unbalances as well as inflammation, thus providing novel therapeutic opportunities. This work discusses critically, through literature review and personal contributions, these novel nonantibiotic treatment strategies for infectious disease management and resistance prevention, which could represent a paradigm change rocking the foundation of current antibiotic therapy tenets.
\end{abstract}

Keywords: infectious diseases; 3-indole carboxaldehyde; microbiota; host-microbiota-pathogen interface; antimicrobial resistance; postbiotics; tryptophan metabolites

\section{Introduction}

The emergence of antimicrobial resistance (AMR) is alarming public health systems worldwide. The emergence of antibiotic resistance leads to an increased risk of therapeutic failure, longer hospitalization, relapses, and greater costs for the health care system. The main challenge in the fight against AMR is the poor efficacy of most of the available treatments, which results in limited prevention or control [1]. Therefore, infections, such as pneumonia, tuberculosis, and foodborne disease are becoming harder to treat [2]. AMR infections are associated with increased mortality, morbidity, and lower quality of life related to the need for difficult, lengthy, and expensive treatments. Resistant pathogens demand more aggressive multiple drug regimens with a high risk of adverse effects and, in some cases, ultimate therapy discontinuation. These regimens often require inpatient settings and long and costly hospitalization. The increased failure frequency of antibiotic treatments raises questions on whether current strategies against AMR will succeed or we are relentlessly heading towards a post antibiotic era [3].

Current reports count 700,000 deaths each year in the world caused by AMR infections. In the US alone, 35,000 deaths a year occur from untreatable infections and mortality is estimated to rise to 10 million new cases by 2050 worldwide [4], alarming numbers that pushed the World Health Organization to warn for urgent interventions [5].

The overuse and misuse of antibiotics in health care, agriculture, food industry, and farming, including unnecessary or incorrect prescriptions, poor patient compliance, and rapid bacterial 
evolution in response to bactericidal selective pressure tools, have contributed to the rising resistance. Such mismanagement along with poor diagnostic tools and depotentiated discovery and development pipelines are major roots to the current crisis $[4,6,7]$. In addition, concern is growing around emerging viral infections, such as the current COVID-19, that have been linked to an increased risk of antibiotic abuse and AMR [8].

For a more insightful understanding of the worrying antibiotic crisis, we recommend the reader to refer to more focused recent literature [9-14].

In light of the above considerations, breakthrough strategies surpassing classical antibiotic mechanisms are therefore needed to overcome AMR.

Antibiotic treatment alters the population structure of the microbiota, with transient and persistent effects on bacterial diversity and population composition. These changes in the microbial community alter resource availability and interspecies communication, with increased chances for pathogen intrusion and colonization resistance loss [15]. Antibiotic treatment can determine selection of antibiotic-resistant populations and transmission of resistance genes in the microbiome [15]. Thus, more selective approaches affecting pathogens while leaving commensals unharmed is gaining ground.

It is by now clear that tackling deadly infections demands novel strategies not only based on the mere toxicity of anti-infective compounds. The arsenal in the hands of microorganisms is by far exceeding the tools available to prevent and defeat bacterial resistance. Moreover, a growing amount of evidence connects host-microbiota dysregulation to human diseases, which warns further against antibiotic abuse and indiscriminate prescriptions [16-19].

This growing awareness prompts new approaches to fight infections, even owing to a deeper comprehension of the complex host-microbiota relationship and how the preservation of such a delicate balance impacts human health.

\section{Nonantibiotic Based Therapies}

Current alternative approaches to antibiotics encompass a wide range of possible treatment options, including phage therapy [20], novel vaccines [21], peptides [22], antimicrobial metals [23], and biofilm targeting [24,25], to name a few, with limited success [26-28].

Other options have stemmed from the evidence that, albeit challenging, AMR could be treated using factors with pleiotropic mechanisms of action that have the ability to interfere with the molecular pathways required by the pathogen for replication and/or persistence, enabling host-mediated responses to infection. These so-called host directed therapies (HDTs), enhancing protective immune signatures, reducing exacerbated inflammation, or balancing immune reactivity at the infection site, represent one of the major alternative approaches against AMR [29-32].

Some HDTs exploit the repurposing of drugs commonly used in therapy and that target specific pathways [33-36]. For instance, metformin has been tested in Mycobacterium tuberculosis infections $[29,37]$ since, by activating the $5^{\prime}$-adenosine monophosphate-activated protein kinase (MAPK), it interferes with the mitochondrial respiratory chain, inducing the production of reactive oxygen species and macrophage activation. Other repurposed drugs to treat epilepsy [38], peptic ulcers [39], cancer [40], anti-inflammatory drugs [41-46], antibodies [47-49], and hypoglycemic compounds [50] or sphingosine-1-phosphate receptor agonists [51] have been investigated.

Micronutrients and immune-modulators, like the granulocyte-macrophage colony-stimulating factor and interferon (IFN)- $\gamma$, are used to boost immunity in patients with sepsis [52-54]. Moreover, antimicrobial peptide inducers, such as 1,25-dihydroxyvitamin D3 and phenylbutyrate [55-58], and checkpoint inhibitors, such as programmed cell death-1 inhibitors, are currently in the spotlight for the efficacy in unleashing the immune system for the treatment of chronic infections, such as tuberculosis [59] (Table 1). 
Table 1. Examples of antimicrobial host directed therapies (HDTs) and mechanisms of action (not intended to be exhaustive).

\begin{tabular}{|c|c|c|c|c|}
\hline Pathogen & & & Mechanisms of Action & Ref \\
\hline \multirow{6}{*}{$\begin{array}{l}\text { Mycobacterium } \\
\text { tuberculosis }\end{array}$} & Repurposed drug & $\begin{array}{l}\text { Imatinib, verapamil, } \\
\text { metformin, ibuprofen }\end{array}$ & $\begin{array}{l}\text { Modulation of inflammation and } \\
\text { activation of intracellular } \\
\text { antimicrobial defenses }\end{array}$ & {$[29,37-42]$} \\
\hline & Cytokine therapy & $\begin{array}{l}\text { IL-2, GM-CSF, INF- } \gamma \text {, } \\
\text { IL-12 }\end{array}$ & $\begin{array}{l}\text { Induction of pro-inflammatory } \\
\text { cell signaling }\end{array}$ & [33] \\
\hline & Monoclonal antibody & $\begin{array}{l}\text { Anti-TNF } \alpha, \text { anti-IL-6, } \\
\text { anti-VEGF }\end{array}$ & $\begin{array}{l}\text { Reduction of tissue-destructive } \\
\text { inflammation by } \\
\text { cytokine neutralization }\end{array}$ & [34] \\
\hline & Monoclonal antibody & $\begin{array}{l}\text { Anti-PD-1, anti-LAG3, } \\
\text { anti-CTLA-4 }\end{array}$ & $\begin{array}{l}\text { Activation and mobilization of } \\
\text { antigen-specific T cells by immune } \\
\text { checkpoint inhibition }\end{array}$ & {$[35,44]$} \\
\hline & Vitamin & Vitamin D3 & $\begin{array}{l}\text { Activation and augmentation of } \\
\text { intracellular antimicrobial defenses } \\
\text { (via IFN- } \gamma \text { and IL-15 signaling) }\end{array}$ & {$[41,42]$} \\
\hline & Cellular therapy & $\begin{array}{l}\text { Autologous } \\
\text { mesenchymal stromal } \\
\text { cells, T cells }\end{array}$ & $\begin{array}{l}\text { Neutralization of tissue-destructive } \\
\text { inflammation, enhancement of organ } \\
\text { repair, and potentiation of } \\
\text { antigen-specific immune responses }\end{array}$ & [36] \\
\hline \multirow{3}{*}{$\begin{array}{l}\text { Streptococcus } \\
\text { pneumoniae }\end{array}$} & \multirow[t]{3}{*}{ Repurposed drugs } & Prednisone & $\begin{array}{l}\text { Reduction of tissue-destructive } \\
\text { inflammation by activating the } \\
\text { glucocorticoid pathway }\end{array}$ & [44] \\
\hline & & $\begin{array}{l}\text { Ibuprofen, statins, } \\
\text { indometacin, aspirin }\end{array}$ & $\begin{array}{l}\text { Reduction of tissue-destructive } \\
\text { inflammation by inhibiting } \\
\text { prostaglandin release via } \\
\text { cyclooxygenase inhibition, regulation } \\
\text { of MHC molecules }\end{array}$ & {$[45,46]$} \\
\hline & & Glibenclamide & $\begin{array}{l}\text { An oral hypoglycemic agent that } \\
\text { modulates voltage-gated calcium } \\
\text { channels, leading to } \\
\text { immunomodulatory effects }\end{array}$ & [50] \\
\hline \multirow[t]{2}{*}{ Bordetella pertussis } & Repurposed drug & Fingolimod & $\begin{array}{l}\text { Activates the } \\
\text { sphingosine-1-phosphate pathway to } \\
\text { improve antigen-specific lymphocyte } \\
\text { responses, as well as reduced } \\
\text { hyper-inflammation }\end{array}$ & [51] \\
\hline & Monoclonal antibody & $\begin{array}{l}\text { Antipertussis toxin } \\
\text { antibodies }\end{array}$ & $\begin{array}{l}\text { Reduces toxin load via infusion of } \\
\text { intravenous immunoglobulins }\end{array}$ & [47-49] \\
\hline
\end{tabular}

Being the pathogen not targeted, HTDs avoid selective pressure on the microbe and, hence, the risk of developing resistance to treatment is small, thus opening a new trove of possibilities.

A recent holistic approach to antibiotic therapy, able to rescue the dysfunctional host-pathogen interaction, can spark novel opportunities for therapeutic innovation. This new approach exploits microbial therapeutics that, rather than damaging the human host and disrupting the microbial ecosystem, increase the fitness of both. This can result in several benefits: (i) a salutary symbiosis, (ii) reduced selection for additional antibiotic resistance genes, and (iii) decreased transmission rates of antibiotic-resistant bacteria by decolonization of patients and the surrounding community [60].

Indeed, combined with the interest in HDTs, advances in the human microbiome research have produced evidence that the biotic balance is a determinant factor in human health. Antibiotics interfere on the microbiome-immune system axis, resulting in immunological disorders [61,62], and also increase host's susceptibility to pathogens [63-66]. It is obvious that the overuse of broad-spectrum antibiotics should be rapidly replaced with more specific approaches and complemented with efficient methods to restore the altered microbiome.

\section{The Microbiota Relevance in Human Infections}

Infectious disease treatments are undergoing a crucial paradigm shift as the intricate interactions between the human microbiota, defined as the community of microorganisms themselves, the immune system, and human pathogens are slowly being untwined. 
An increasing amount of evidence strongly supports the crucial role of the human microbiome in human health and disease [67-69]. As a result, the microbiota has become an attractive target for potential therapeutics [70].

\subsection{The Host-Gut Microbiota Interface}

It is today clear that trillions of microbes colonize all districts of the human body. The human microbiota contributes to human health due to a natural symbiosis that develops with the host shortly after birth. This reciprocal supporting function of the microbiota is today virtually recognized in different organs and compartments. The microbiota composition and function differ according to location, host's factors, and lifestyle, which determine individual specificity [71]. Currently, the most characterized microbiota is the gut microbiota (GM) [72].

A growing body of evidence, collected through advanced sequencing technologies, underpins the relationship between the changes in the GM composition and diseases. The GM functions by supporting the integrity of the mucosal barrier, providing nutrients, and preventing pathogen invasion. Since the microbiota-mucosal immune system interaction is critical for the host's immune balance, alterations in the GM composition and function can result into several ailments, including diabetes, obesity, asthma, cancer, cystic fibrosis [73], inflammatory bowel disease (IBD) [74,75], chronic liver disease [76], atopic dermatitis (AD) [77], and chronic mucocutaneous candidiasis [78]. Therefore, the GM equilibrium may be crucial for the delicate balance of the whole-body function and health. Such an important role of the GM seems to be attributable, at least in part, to the production of microbiota-derived metabolites.

\subsection{Antibiotics and the Gut Microbiota}

A considerable research effort has been focused on the comprehension of the link between the effect of antibiotics on specific bacterial populations within the GM and the emergence of drug resistance [79-81].

By decreasing the diversity of the microbiota, antibiotics can cause outgrowth of certain bacterial populations, which can convert to pathogens themselves or favor the invasion of alien microbes [82]. Such conditions result in a number of serious pathologic disorders, as in the case of Clostridium difficile infections, where the toxins released by the microbe damage the epithelium, leading to inflammation and cell death.

The antibiotic induced alteration of the microbiota perturbates the mucosal pattern recognition receptor (PRR) signaling and the secretion of antimicrobial peptides and impairs the development and function of intestinal immune cells. Innate lymphoid cells (ILC3) play a fundamental role, via an Interleukin (IL)-22-dependent pathway, in the blocking bacteria translocation through the intestinal epithelium. By impacting the ILC3 group recruitment and development, antibiotics knock down IL-22 production, an important cytokine for intestinal homeostasis, augmenting host susceptibility to invading pathogens [83]. Likewise, the GM disruption can dysregulate the T-helper (Th) 1 to Th2 cell ratio, the differentiation of naive $\mathrm{T}$ cells into regulatory $\mathrm{T}$ cells, and deplete the Th17 cell population [84]. A dysbiotic microbiota loses its fundamental regulatory role [85] thereby resulting in metabolic, immunological, and developmental disorders as much as susceptibility to infections [86-89].

\subsection{Microbiota-Based Therapeutics}

It is today accepted that the GM modulation can be useful to manage gastrointestinal disorders. A dysbiotic microbiota can be prevented by supplying microorganisms to restore impaired microbial populations and to enhance the intestine resiliency to infection. In this regard, prebiotics, probiotics, fecal microbiota transplantation (FMT), and bacteriophage therapy are major treatment options (Table 2). 
Table 2. Examples of microbiota-based therapeutic strategies and development phase (not intended to be exhaustive).

\begin{tabular}{|c|c|c|c|c|c|}
\hline \multicolumn{2}{|c|}{ Microbiota Based Therapies } & \multicolumn{2}{|c|}{ Symptomatology } & Trials & Reference \\
\hline \multirow{5}{*}{ Bacteriophages } & $\begin{array}{c}\text { Muddy, } \\
\text { BPs33 } \Delta \text { HTH-HRM10, and } \\
\text { ZoeJ } \Delta 45\end{array}$ & Cystic fibrosis & Mycobacterial infection & Clinical case study & [90] \\
\hline & ОМКО1 & $\begin{array}{l}\text { Prosthetic vascular } \\
\text { graft infections }\end{array}$ & Pseudomonas aeruginosa & Preclinical & [91] \\
\hline & PP1131 cocktail & $\begin{array}{l}\text { Burn wounds } \\
\text { infected }\end{array}$ & Pseudomonas aeruginosa & Phase I-II & [92] \\
\hline & Myoviridae & Enteric infection & Escherichia coli & Preclinical & [93] \\
\hline & phage cocktail & $\begin{array}{l}\text { Burn wound } \\
\text { infections }\end{array}$ & Klebsiella pneumoniae & Preclinical & [94] \\
\hline \multirow{3}{*}{\multicolumn{2}{|c|}{ FMT }} & \multicolumn{2}{|c|}{ Clostridium difficile } & Preclinical & [95] \\
\hline & & \multirow{2}{*}{\multicolumn{2}{|c|}{ Ulcerative colitis }} & Phase II & [96] \\
\hline & & & & Phase II & [97] \\
\hline Probiotics & $\begin{array}{l}\text { Lactobacillus acidophilus } \\
\text { Saccharomyces boulardii } \\
\text { Lactococcus lactis, } \\
\text { Lactobacillus rhamnosus, } \\
\text { Lactobacillus plantarum, } \\
\text { Lactobacillus casei, } \\
\text { Lactobacillus reuteri, } \\
\text { Lactobacillus plantarum, } \\
\text { Bifidobacterium infantis }\end{array}$ & \multicolumn{2}{|c|}{$\begin{array}{c}\text { Traveler's diarrhea, } \\
\text { Antibiotic-associated diarrhea, Ulcerative } \\
\text { colitis Crohn's disease, } \\
\text { Atopic dermatitis, } \\
\text { Clostridium difficile Irritable bowel syndrome }\end{array}$} & Phase II & [98-101] \\
\hline
\end{tabular}

\subsubsection{Fecal Microbiota Transplantation}

Opportunistic antibiotic-resistant infections, such as those from C. difficile, can be fought by supplying fecal microbes $[102,103]$. Healthy fecal microbes engage niche competition with the pathogen, suppressing $C$. difficile propagation through the production of growth inhibitors. FMT can indeed limit the transmission of resistance and extend the viability of antibiotics. Albeit FMT could contribute to the eradication of multidrug-resistant bacteria, the risk for local and bloodstream infections has raised safety concerns in immunocompromised patients [104].

\subsubsection{Bacteriophages}

Bacteriophages represent the major viral components of the GM and contribute to several GM features, such as microbial composition and diversity as well as horizontal gene transfer [105-109]. Bacteriophages directed against specific bacterial strains can be another viable option against AMR [110]. Bacteriophages show efficacy against biofilm-associated infections, such as methicillin-resistant Staphylococcus aureus [111] and P. aeruginosa infections [112]. In spite of the major advantages over antibiotics, such as host-specificity [113], phage therapy, like antibiotic treatment [114], may induce fast endotoxin release due to cell lysis. In part, such a drawback, along with phage regulatory gaps and incompliances, have contributed to halt phage therapy approval for human use [115]. However, emerging initiatives, such as the phage therapy framework initiative based on magistral preparations that Belgium has recently undertaken [116], may help to tackle and overcome the above-mentioned issues and underpin an expedited transfer to the clinic.

\subsubsection{Probiotics and Prebiotics}

The majority of the current microbiota-based therapeutics target the modulation of intestinal microbial composition through exogenous administration of live microbes, termed probiotics. Probiotics, by definition, are expected to benefit human health and their market has expanded tremendously over the last decades. However, hostile mobile genetic elements have been frequently documented to transfer to and from probiotics [117]. In this regard, antibiotic-resistant genes have been detected in various dietary supplements [118]. Moreover, probiotics have been found capable of 
secreting an enzyme, identified as a potential etiologic factor in celiac disease [119-122], and partially failed to produce a significant change on the GM population [123-126]. In addition, probiotic effects decrease significantly with time in mice [126] and their function markedly declines in products upon storage [127]. Alternative to probiotics, prebiotics are compounds capable of influencing microbiome composition or function in a non-specific and beneficial way. A combination of both, namely synbiotics, is being investigated with as of yet insufficient evidence and unclear benefits $[128,129]$.

Lately, a number of systematic reviews, a meta-analysis, and expert opinions have expressed criticism on the probiotics and prebiotics claimed effects and safety [130-136].

\section{Postbiotics: The Changing Paradigm}

A new frontier is emerging as a result of a deeper understanding of the role of microbiota derived metabolites, termed postbiotics, in human diseases, which may enable novel therapeutic approaches [137,138].

Upon responding to nutritional cues within the host microenvironment, bacteria generate a large number of metabolites, many of which have undefined biological functions. The metabolites produced by one class of bacteria can influence antibiotic susceptibility of the neighboring bacteria within a niche. Progresses in high-throughput sequencing and metabolomics have promoted the identification of a series of postbiotic compounds that can contribute to directly and specifically manipulate the microbiota and host functions [139]. Many of these postbiotics derive from the transformation of specific dietary components by specialized microbe species expressing the required enzymes $[140,141]$.

Noteworthy, the large variability of the GM composition among individuals reflects on its metabolic and functional phenotype, which explains the large array of microbial-derived metabolites among the population [142].

Metabolomic studies have stressed that the microbial metabolite population remarkably differs between diseased and healthy subjects $[143,144]$. The disruption of the host-microbiota balance leads to a number of intestinal and extra-intestinal diseases. Gao et al. discovered that mice fed with butyrate-enriched high-fat diet have increased thermogenesis and energy expenditure and were less prone to obesity than control mice [145]. Moreover, Rouse et al. [146] demonstrated that pre-treatment with dietary indole derivatives, such as 3-indolelactic acid (3IA) and diindolylmethane, prevents the development of experimental autoimmune encephalomyelitis. On the other hand, Koeth et al. showed that the microbial metabolism of dietary L-carnitine produces trimethylamine- $\mathrm{N}$-oxide and accelerates atherosclerosis in mice [147].

Therefore, evidence is continuously emerging on the importance of such molecules that can play a bridge role between the host and the microbe. Potentially, these natural compounds may be exploited to generate a new class of therapeutics not aiming at the elimination of the invading microorganisms, but rather at manipulating the crosstalk among bacteria and the host to restore a healthy balance.

Postbiotics are physiologically abundant at variable concentrations with low toxicity concerns, showing defined chemical structures, safety dose parameters, and long shelf life (up to 5 years as dietary supplements) $[148,149]$, features that make them highly therapeutically attractive. Moreover, Shenderov and co-workers [150] have reported that these compounds show suitable features for absorption, synthesis, transmission, and excretion, which could suggest a high capacity to signal various organs and tissues in the host, resulting in several biological responses.

In general, postbiotics have been recognized as being responsible for biologically relevant local and systemic effects dependent on the qualitative and quantitative composition of the GM. Several of these metabolites are found in many extra-intestinal tissues and impact significantly on the intestinal immune homeostasis, vascular function, neurological behavior, and energy metabolism [151-153] (Table 3). 
Table 3. Main postbiotic classes and their biological activities (adapted form 254).

\begin{tabular}{|c|c|c|}
\hline Metabolite & Activities & Reference \\
\hline Butyrate, acetate, propionate & $\begin{array}{l}\text { Preserve mucosal immunity } \\
\text { Enhance the regulatory function of Tregs in the large intestine } \\
\text { Butyrate suppresses proliferation by acting as a HDAC inhibitor } \\
\text { Enhance the protection against infections } \\
\text { Activate GPR43 and GPR109a on intestinal epithelial cells, result in the } \\
\text { activation of the NLRP3 inflammasome leading to production of IL-18. } \\
\text { NF-kB inactivation and suppression of pro-inflammatory cytokines and nitric } \\
\text { oxide in neutrophils and mononuclear cells through HDAC inhibition }\end{array}$ & [154-168] \\
\hline Niacin & $\begin{array}{l}\text { Induces anti-inflammatory properties in dendritic cells and macrophages in a } \\
\text { GPR109a-dependent manner and suppresses colonic inflammation }\end{array}$ & [160] \\
\hline Retinoic acid & $\begin{array}{l}\text { Dendritic cell induction of gut-lymphocytes } \\
\text { Supports the development of Tregs through TGF- } \beta \text { and suppresses the } \\
\text { development of TH17 cells during inflammation, RA is required for the } \\
\text { induction of a proinflammatory CD4+ helper T cell response }\end{array}$ & [169-172] \\
\hline Polysaccharide A (PSA) & $\begin{array}{l}\text { Suppresses the production of pro-inflammatory IL-17 and promotes expression } \\
\text { of IL-10 by CD } 4+\text { T cells }\end{array}$ & {$[156,173,174]$} \\
\hline Bile acids & $\begin{array}{l}\text { Regulation of bacterial growth } \\
\text { Inhibit the induction of pro-inflammatory genes through NF-kB }\end{array}$ & [175-177] \\
\hline Taurine & Nlrp6 inflammasome activation and contribution to intestinal homeostasis & [178] \\
\hline Indoles & $\begin{array}{l}\text { Induce IL-22 secretion by ILCs, further driving the secretion of antimicrobial } \\
\text { peptides and protection from infections by pathogens } \\
\text { Epithelial barrier enhancement }\end{array}$ & {$[56,179,180]$} \\
\hline
\end{tabular}

\subsection{Major Postbiotic Groups}

Postbiotics can be classified by their chemical nature, such as lipids, carbohydrates, proteins, organic acids, vitamins/co-factors, peptidoglycan-derived muropeptides, or lipoteichoic acids, or by their physiological functions, including immunomodulation, anti-inflammatory, hypocholesterolemic, anti-obesogenic, anti-hypertensive, anti-proliferative, and antioxidant activities $[149,181]$ (Table 4).

Table 4. Microbial derived metabolites and their biological targets.

\begin{tabular}{|c|c|c|c|c|c|}
\hline Source & Bacteria & Microbial Metabolite & Family & Receptor & Reference \\
\hline $\begin{array}{l}\text { Dietary Tryptophan } \\
\text { (microbial origin) }\end{array}$ & $\begin{array}{l}\text { Firmicutes, Lactobacillus, } \\
\text { Clostridium, Bacteroides }\end{array}$ & $\begin{array}{c}\text { 5-hydroxy-tryptophan } \\
\text { Tryptamine } \\
\text { Indoleacetic acid } \\
\text { 3-methylindole (Skatole) } \\
\text { 3-indole carboxaldehyde } \\
\text { Indole-3-sulfate } \\
\text { Indole propionic acid } \\
\text { 3-indolelactic acid }\end{array}$ & $\begin{array}{l}\text { Indole and } \\
\text { Indole } \\
\text { derivatives }\end{array}$ & AhR, PXR & {$[179,183,184]$} \\
\hline Bile acids & $\begin{array}{c}\text { Bacteroides, Bifidobacterium, } \\
\text { Clostridium, Lactobacillus, } \\
\text { Eubacterium }\end{array}$ & $\begin{array}{l}\text { Deoxycholic and } \\
\text { lithocholic acid }\end{array}$ & $\begin{array}{l}\text { Secondary } \\
\text { bile acids }\end{array}$ & $\begin{array}{l}\text { GPBAR1, } \\
\text { FXR }\end{array}$ & {$[185,186]$} \\
\hline Dietary choline & $\begin{array}{c}\text { Actinobacteria } \\
\text { Bacteroidetes Firmicutes } \\
\text { Proteobacteria }\end{array}$ & Trimethylamine-N-oxide & Amine oxides & FXR & {$[190,191]$} \\
\hline Ginseng & Bacteroides & Compound K & Ginsenosides & GPBAR1 & {$[124,192]$} \\
\hline
\end{tabular}

The main postbiotics groups are:

1. Carbohydrate metabolites-anaerobic bacteria produce short-chain fatty acids (SCFAs) through carbohydrate fermentation in the intestine. They are formed starting from polysaccharide, oligosaccharide, protein, peptide, and glycoprotein precursors [193]. In particular, bacteria of the 
Bacteroidetes phylum are good producers of acetate and propionate SCFAs, whereas those in the Firmicutes phylum are efficient butyrate producers [194].

2. Amino acid and related metabolites-proteins are metabolized by many bacterial species, such as Bacillus, Clostridium, Streptococcus, Lactobacillus, and Proteobacteria phyla.

3. Lipid and bile acid metabolites - the GM alters bile acids through various modifications [195]. More than 20 different secondary bile acids are generated, including deoxycholic acid and lithocholic acid, as well as phosphatidylcholine is metabolized to produce trimethylamine- $\mathrm{N}$-oxide.

Several host cell receptors can sense microbial metabolites: (i) purinergic receptors, such as $\mathrm{P}_{2} \mathrm{X}_{7}$, detect microbial and host-derived nucleotides [196], (ii) the membrane bile acid receptor and Farnesoid X receptor bile acids and xenobiotic metabolites [197,198], (iii) G-protein-coupled receptors (GPRs), such as GPR43 and GPR41, SCFAs, and (iv) the aryl hydrocarbon receptor (AhR) and pregnane X receptor (PXR) tryptophan (Trp), indole, bile acids, and toxicant metabolites [199-201] (Table 4).

\subsection{Targeting of the Host-Microbiota-Pathogen Interface}

Some postbiotics seem to play a dual role during bacterial infections by acting on the pathogen while strengthening the host's resistance to disease and immunopathology. Although the relative mechanisms are not fully understood, postbiotics functional properties encompass anti-inflammatory, immunomodulatory, and antimicrobial that avail microbiota homeostasis and/or host metabolic and signaling pathways $[82,83,202]$. Here below, the main recognized ways and functions by which postbiotics can exert their potential therapeutic role are briefly discussed.

\subsubsection{Signaling Molecules}

Postbiotics can mediate the host-microbe communication. Some postbiotics act on downstream signaling pathways of the microbiome, rescuing directly or indirectly the relative dysregulated processes. As such, they have the potential to counteract and correct the negative effects of dysbiosis as well. Through PRRs, such as NLRs (nucleotide-binding oligomerization domain and leucine-rich repeat-containing receptors), the host can recognize microbial elements, which can result into downstream antimicrobial responses or tolerance [203].

The SCFA butyrate has shown a double role in cellular metabolism and as a signaling molecule [86]. SCFAs are agonists for several GPRs on the cell surface, such as GPR43 and GPR41 [204,205], thus activating MAPKs, the extracellular-signal-regulated kinase 1 and 2, c-Jun N-terminal kinase and p38/MAPK [206]. Moreover, being able to translocate inside cells via active transport by the sodium-coupled monocarboxylate transporter $1[207,208]$, SCFAs affect transcriptional regulation by inhibiting nuclear class I histone deacetylases (HDACs) and activating histone acetyltransferases. As reported by Steliou et al. [209], butyrate and, to a lesser extent, propionate are known to act as HDAC inhibitors [210,211]. Furthermore, Alex and coworkers [212] attributed to butyrate the ability to act as an agonist for the peroxisome proliferator-activated receptor- $\gamma$, with a consequential impact on fatty acid deposition and glucose metabolism.

\subsubsection{Enhancement of Epithelial Barrier Function}

Postbiotics can promote colonization resistance by enhancing barrier function within the epithelial lining. Elamin et al. [213] showed that butyrate exerted a protective effect on the intestinal barrier function in Caco-2 cell monolayers by upregulating the expression of mucin 2 [214], which structurally reinforced the mucous layer and enhanced the protection against luminal pathogens. Levy et al. [178] demonstrated that exogenous polyamines, such as spermine and monoamine histamine, reducing the release of IL-18, an epithelial repair and barrier protective cytokine, can damage the intestinal epithelium by inhibiting the activation of the NLRP6 inflammasome. Taurine, an endogenous bile acid derived microbial metabolite, successfully contrasted the negative spermine and histamine effects, indicating a finely tuned balance of opposing bacterial stimuli [178]. Furthermore, Assa et al. [215] 
investigated the impact of vitamin D deficiency on the infection-related perturbation of the intestinal epithelial barrier in vitro and on Citrobacter rodentium-induced colitis in mice, a pathological condition that causes increased colonic permeability to macromolecules [216]. Vitamin D deficiency further increased intestinal paracellular permeability, supporting the vitamin D role in maintaining the epithelial barrier mucosal integrity.

\subsubsection{Immunomodulatory Activity}

Postbiotics have been found to stimulate anti-inflammatory immune responses and act as immunomodulators in various animal models [148].

Potential metabolite therapeutics include SCFAs, owing to a demonstrated anti-inflammatory activity and an observed alteration in certain diseases, such as IBD [163,217,218]. Maciejewska et al. revealed altered butyrate levels in high fat diet models $[219,220]$. Butyrate promotes the differentiation of the colonic and small intestine Tregs, crucial for intestinal homeostasis, through GPRs, including GPR41, GPR43, and GPR109A. GPRs are known for being involved in NLRP3 inflammasome activation as well [101]. Venegas and coworkers [221] showed that SCFAs exert anti-inflammatory effects on the intestinal mucosa by HDACs inhibition and by activating the GPRs present in the intestinal epithelial cells and immune cells. Moreover, Cox et al. [222] demonstrated that SCFAs were capable of inducing prostaglandin E2 release and the expression of IL-10 through pertussis toxin-sensitive GPRs, thereby inhibiting inflammatory responses in human monocytes. Additionally, flavonoids have been implicated in therapies for metabolic diseases [223] owing to their ability to interfere with inflammatory signaling [224]. In a mouse model of metabolic syndrome, Rivera et al. [225] showed as the administration of quercetin increased plasma concentration of adiponectin, reduced the tumor necrosis factor- $\alpha$ secretion and the expression of the proinflammatory inducible nitric oxide synthase in visceral adipose tissue. Son et al. [226] observed that taurine reduced inflammation in rat models of IBD, thus decreasing colonic damage and the incidence of diarrhea. Additionally, Lactobacilli derived postbiotics have been found to reduce tissue inflammation by modulating the inflammatory mediator secretion and nuclear factor- $\kappa \mathrm{B}(\mathrm{NF}-\kappa \mathrm{B})$ activation [227-230]. On the other hand, recent works have shown that higher trimethylamine- $\mathrm{N}$-oxide levels induced the activation of the NF-kB pathway and increased the expression of pro-inflammatory cytokines, adhesion molecules, and chemokines [191,231].

\subsubsection{Antimicrobial Activity}

Several known and unknown postbiotic compounds, such as bacteriocins, enzymes, small molecules, and organic acids, exhibit bacteriostatic or bactericidal properties against both Gram-positive and Gram-negative microorganisms [232]. For instance, nisin A, produced by Lactococcus lactis, is a pore-forming bacteriocin that binds the peptidoglycan precursor lipid II preventing its binding with penicillin and leading to rapid cell death [233]. Synergism between bacteriocins and commensals like L. acidophilus has been reported and this combined action was able to inhibit the growth of Salmonella enterica, S. aureus, and Bacillus cereus [233]. Vilchèze et al. [234] revealed the ability of vitamin C to impair bacterial biofilm formation by inhibiting the production of extracellular polymeric substances.

\subsubsection{Antiproliferative Activity}

Not surprisingly, the host-GM axis may affect cancer genesis and development as well. Postbiotics have also shown antiproliferative activity against colon cancer cells, likely by controlling immune responses and through the activation of pro-apoptotic cell death pathways $[235,236]$. In particular, butyrate and propionate inhibited host's tumor cell HDACs by a mechanism that is still obscure. Flavonoids, such as quercetin, suppressed tumor growth by inhibiting protein tyrosine kinases in colon cancer cells [237]. Anthony et al. [238] reported anti-proliferative apoptotic effects of indole-3-carbinol (I3C), produced by Trp metabolism, on human breast cancer cells. I3C showed an anti-proliferative response by selectively stimulating the interactions between the stem/progenitor 
cell marker nucleostemin with murine double mutant 2, which triggered the p53 apoptotic response. Furthermore, Sreenivasa and coworkers [239] revealed the I3C ability to inhibit cell growth and induce apoptosis in prostate cancer cells by inhibiting the NF- $\mathrm{kB}$ activation.

The many implications of the above-mentioned properties and ways of action of postbiotics infer their potential pivotal role as drivers for the development of personalized therapies aiming to manipulate the host microbiota [137]. The following section describes the nature and known mechanisms of the most promising compounds so far identified, focusing specifically on indoles.

\section{Tryptophan-Derived Postbiotics: Indoles}

The complex host-microbiota crosstalk is modulated by a large array of metabolites. Among all, Trp metabolites take a center stage.

Trp is one of the nine essential amino acids supplied by diet and its metabolic pathways generate a number of key molecular modulators of the GM [240,241]. Such metabolites are of both host and microbial origins. The $99 \%$ of diet Trp is metabolized along three major pathways in the gastrointestinal tract: (i) via specific bacterial strains into indole and indole derivatives (microbial origin) [143,144], (ii) via the kynurenine pathway in both immune and epithelial cells by indoleamine 2,3-dioxygenase 1 (host origin) [242], and (iii) via the serotonin production pathway in enterochromaffin cells by $\operatorname{Trp}$ hydroxylase 1 (host origin) [243].

The enzyme tryptophanase, expressed in many Gram-negative and Gram-positive bacterial species including E. coli, Clostridium spp., and Bacteroides spp. leads indole formation [151,244-247]. Clostridium spp. convert Trp into tryptamine, 3-indolelactic acid (ILA) and indole propionic acid [143,248,249]. Likewise, Peptostreptococcus spp. are known to convert Trp in indole acrylic acid and indole propionic acid. Lactobacillus spp. convert Trp to 3-indole-carboxaldehyde (3-ICA) and ILA via the aromatic amino acid aminotransferase and an indoleacetic acid dehydrogenase $[179,250]$. Several Bacteroides species have been reported to produce ILA and indoleacetic acid [251], whereas Bifidobacterium spp. to produce ILA [251,252].

Indoles are a major class of postbiotics that has gained considerable credit owing to their capacity to extend health span across a broad range of evolutionarily diverse species from different phyla [253]. The indole and indole derivatives synthesized in the gastrointestinal tract act as a possible link to microbiota dysbiosis by affecting host immune reactivity, epithelial barrier function, and pathogen colonization [254]. These compounds seem to function through a what could be defined as a two-faced Janus's mode of action across the intertwining liaisons connecting the host and microbes as explained below.

\subsection{Indoles at the Microbiota-Pathogen Interface-Indoles as Quorum Sensing Signals}

The appraisal of indole as a quorum sensing (QS) molecule is of relatively recent origin [245]. As an intercellular signaling molecule, indole controls spore formation, plasmid stability, drug resistance, and biofilm formation [255-259]. Recent works have unraveled the indole role in the acquisition of antibiotic resistance through the formation of antibiotic-tolerant persister cells through probable oxidative stress and phage shock pathways [259], which supports the hypothesis that indole is involved in antibiotic resistance processes via multidrug transport [260-262]. Chimerel et al. [263] showed that indole could act as a proton ionophore and inhibit cell division by reducing the electrochemical potential when indole crosses the membrane. Kim et al. [264] demonstrated that indole caused toxicity to P. putida and interfered with protein folding. Highly expressed genes coding for proteases, molecular chaperones, and tricarboxylic acid cycle enzymes can play crucial roles in indole-induced stress conditions. Indole has been reported to act as an antivirulence compound against E. coli, P. aeruginosa, and S. aureus [255-257,265]. Lee et al. [256] demonstrated that indole modulates the expression of virulence and regulatory genes, previously reported as being substrate for the P. aeruginosa QS system. 


\subsection{Indole at the Host-Microbiota Interface-Indoles as an Intercellular Signal in Microbial Communities}

The functional effects of certain indoles can be sorted into two categories: (i) integration into host intracellular metabolism and (ii) receptor-mediated metabolite sensing. In the first case, the microbiome supports tissues and organs as an endocrine energy source [266]. In the second case, host's eukaryotic cells recognize microbiome-derived metabolites, which trigger receptor-mediated signaling cascades and cell-specific transcriptional responses either locally or systemically. As reported above for multiple postbiotics, such signaling functions and their interaction with the immune system have been found to particularly characterize indole derivatives [267]. The major recognized indole and indole derivative functions are concisely summarized hereinafter.

Indoles as Ligands of the Aryl Hydrocarbon Receptor

Recent works on indoles generated via microbial metabolism show that several host receptors, which include the AhR and PXR, could be important targets for regulating the host-microbe homeostasis [201,268]. In this section, we focused on the AhR, since its promiscuous ligand binding site is capable of accommodating diverse small bacterial indole metabolites. AhR can be activated by a large number of exogenous-endogenous ligands and, by inducing gene expression, AhR regulates many physiopathological events, such as cell differentiation, proliferation, adhesion, apoptosis, and migration [268,269]. This evidence has sparked new understanding of the AhR signaling pathways and its interaction with endogenous metabolites. It is clear that AhR has multiple functions beyond toxicology, to include developmental biology, and bidirectional communication with the microbiome for tuning host immunity, tolerance, and metabolism [268,270] (Table 5).

Table 5. Microbiota and host metabolites with AhR ligand properties (adapted from [271]).

\begin{tabular}{|c|c|}
\hline Compound & Origin \\
\hline \multicolumn{2}{|c|}{ Indole Metabolites [268,272] } \\
\hline Indole & Dietary metabolite and microbiota metabolism \\
\hline Indolo[3,2-b] carbazole & Dietary metabolite \\
\hline 2-(Indol-3-ylmethyl)-3,3'-diindolylmethane & Dietary metabolite \\
\hline 3,3'-Diindolylmethane & Dietary metabolite \\
\hline \multicolumn{2}{|c|}{ Tryptophan Metabolites [268] } \\
\hline Kynurenine & Host Metabolism \\
\hline Kynyrenic acid & Host Metabolism \\
\hline Zanthurenic acid & Host Metabolism \\
\hline Cinnabarinic acid & Host Metabolism \\
\hline 5-hydroxy-tryptophan & Host Metabolism \\
\hline Tryptamine & Microbiota metabolism \\
\hline Indol-3-acetic Acid & Microbiota metabolism \\
\hline 3-methylindole (Skatole) & Microbiota metabolism \\
\hline 3-indole-carboxaldehyde & Microbiota metabolism \\
\hline Indoxyl-3-sulfate & Microbiota and Host Metabolite \\
\hline \multicolumn{2}{|c|}{ Arachidonic Acid Metabolites [273,274] } \\
\hline Lipoxin 4A & Host Metabolism \\
\hline Prostaglandin -PGG2 & Host Metabolism \\
\hline Hydroxyeicosatrienoic acid & Host Metabolism \\
\hline \multicolumn{2}{|c|}{ Heme-derived [275] } \\
\hline Indigorubin Bilirubin & Host Metabolism \\
\hline Indigo Biliverdin & Host Metabolism \\
\hline
\end{tabular}




\subsection{Regulation of the Immune Response}

AhR is a transcription factor, highly expressed in immune and epithelial cells [275], that serves as a sensing and modulator system for environmental toxins [276]. This response is mediated by innate and adaptive immune cells through alteration of the $\mathrm{CD} 4^{+} \mathrm{T}$ cell polarization into Tregs or Th17 cells. For instance, 6-formylindolo[3,2-b]carbazole, an endogenous Trp metabolite, promotes, via AhR activation, the generation of Th17 cells [277]. Likewise, kynurenine, another Trp metabolite, promotes pTreg generation [278]. Moreover, AhR activation by the xenobiotic ligand 2,3,7,8-tetrachorodibenzodioxin enhances the generation of Tregs from $\mathrm{CD} 4^{+}$cells in vitro and inhibits the production of Th1 and Th17 cells $[279,280]$. AhR promotes Th17 differentiation through different mechanisms, including direct binding to the $I l 17$ gene locus or the inhibition of the signal transducer and activator of transcription 1 phosphorylation, which knocks down Th1 in favor of Th17 differentiation $[280,281]$. Such a regulatory role on the T-cell compartment underpins the AhR potential as a therapeutic target for the treatment of autoimmune disorders [282-286].

\subsection{Regulation of Intestinal Homeostasis}

AhR plays multiple functions, which include antimicrobial defense, tissue protection and repair, and toxin clearance. In fact, AhR activation promotes the modulation of antimicrobial activity via Th17 cell activation [270], increased epithelial barrier function, epithelial cell repair [287], IL-22 mediated protection [179], and control of inflammation via Treg activation [278]. Furthermore, AhR upregulates the cytochrome P450 enzymes enhancing the metabolism of harmful toxicants.

AhR deficiency increased the severity of $T$ cell or sodium dextran sulfate (SDS) induced experimental colitis in mice. In the same models, Zelante et al. [179] associated AhR deficiency related colitis to an altered production of IL-22. Lamas et al. [288] also demonstrated, in mice deficient in the caspase recruitment domain (Card) 9, an IBD susceptibility gene, that the impaired capacity of the dysbiotic GM to catalyze Trp conversion into AhR ligands reflected into lower IL-22 levels and a higher Card9 $9^{-/}$mice susceptibility to SDS-induced colitis. Some evidence exists in humans as well. Monteleone et al. [289] reported as the pharmacological activation of AhR decreases the proinflammatory cytokine IFN $\gamma$ and increases the production of IL-22 in lamina propria mononuclear cells from IBD patients.

The above evidence clearly suggests that the development of suitable postbiotic delivery strategies may greatly benefit the treatment of autoimmune inflammatory and neoplastic diseases as well as antibiotic resistance.

\section{Nonantibiotic Indoles as Novel Therapeutic Tools}

The capacity of certain indoles to act across the host-microbiota-pathogen axis evokes new scenarios in infectious disease treatment and management. Intriguingly, such indoles may enable novel nonantibiotic therapies where killing the microbes is not the primary endpoint. Therefore, by avoiding selective pressure on the pathogen, microbial resistance could be prevented, while likely allowing treatment of multidrug resistant strains.

Preclinical evidence suggests that indole postbiotic-based treatments can either moderate the inflammatory response to infection or limit microbial growth by blocking access to host resources, without exerting toxic antimicrobial effects $[6,290]$. Therefore, modulating bacterial processes not fundamental for cell survival is not supposed to trigger the development of defensive mechanisms. Moreover, a better understanding, at a molecular level, of processes, such as QS, could enable manipulation of the biological signatures allowing prevention or inhibition of the pathogen ability to establish infection.

In fact, pathogens, to colonize the host, must activate QS signaling to proliferate, form biofilms, and produce virulence factors, suggesting that breaking down this bacterial communication by anti-QS agents could make pathogens more susceptible to host immune responses and antibiotics. In this 
regard, combination therapies coupling an antibiotic with an anti-QS agent are currently considered as one of the most effective clinical strategies for the treatment of bacterial diseases [291,292].

\subsection{The Case of 3-Indole-Carboxaldehyde (3-ICA)}

A postbiotic of particular interest is 3-ICA, a Trp metabolite that seems to exert dual beneficial effects on the organism as well as the GM. 3-ICA is abundantly produced by L. reuteri in the gut, via aromatic amino acid aminotransferase, and acts as a ligand of AhR [179]. Considering the previously discussed activity of AhR in protecting from inflammatory damage and maintaining barrier integrity [131], it is not surprising that a diet rich in AhR ligands can prevent or halt tumorigenesis [293] and that restoring AhR signaling rescues metabolic syndrome [294], a disorder characterized by a cluster of diseases, including visceral obesity, low high-density lipoprotein, hypertension, hyperglycemia, and hypercholesterolemia [295]. This rationale has provided the base for the development of 3-ICA delivery approaches aimed at the treatment of dysreactive immune disorders and infections [296,297].

Overall, 3-ICA can exert an important role at the host-microbiota-pathogen interface. We briefly summarize some published and unpublished results below.

\subsubsection{3-ICA Enhances Epithelial Barrier Integrity}

3-ICA is capable of activating ILC3 for IL-22 production via AhR. Sensed by intestinal epithelial cells, IL-22 enhances the epithelial barrier integrity as well as the production of antimicrobial peptides, thus exerting a control over the local microbial load and composition.

Coherently with such premises, 3-ICA administration enhanced the barrier integrity and the production of antimicrobial peptides in murine models of colitis, gastrointestinal, and vaginal candidiasis [78,179]. Thus, the microbe driven IL-22 production $[179,298]$ can untwine how antibiotic-related dysbiosis and cancer therapy may predispose to secondary fungal infections and suggests that therapies aimed at restoring the AhR/IL-22 axis at the mucosal surface could be of therapeutic benefit. To the best of our knowledge, no current or in-development treatments are designed to modulate disease symptoms through epithelial repair.

\subsubsection{3-ICA Reduces Intestinal Inflammation}

In a graft-versus-host-disease murine model, the treatment with 3-ICA decreased intestinal epithelial damage, transepithelial bacterial translocation, and inflammatory cytokine production. 3-ICA treatment also led to recipient-strain-specific tolerance of engrafted $\mathrm{T}$ cells and upregulated the genes associated with the type I IFN response known to protect against radiation-induced intestinal damage. Thus, 3-ICA, by acting through different downstream effector pathways, may limit intestinal inflammation and damage and may provide a therapeutic option for patients at risk for metabolic syndrome, inflammatory bowel diseases, and graft-versus-host-disease [299].

\subsubsection{3-ICA Attenuates Inflammation in Patients with Atopic Dermatitis}

A recent work reported that 3-ICA levels on the skin surface are significantly lower in patients with AD [300]. Topical application of 3-ICA alleviated skin inflammation in a mouse model of AD-like dermatitis, in part through the inhibition of thymic stromal lymphopoietin expression in keratinocytes in an AhR dependent fashion.

\subsubsection{3-ICA Acts as a QS Signaling}

Interestingly, 3-ICA has also been shown to regulate virulence of pathogenic bacteria by interfering with bacterial small-molecule signaling [301]. This finding suggests that the control of the microbial composition and fitness could be an additional mechanism through which 3-ICA may exert its therapeutic efficacy at the host/microbe interface. 
In an in vitro preliminary study on bacterial growth, 3-ICA exhibited potent antimicrobial activity against S. aureus, P. aeruginosa, K. pneumoniae, and, of great potential interest, against K. pneumoniae carbapenemase (Figure 1, Supplementary Materials). Preliminary as they are, these results suggest that the beneficial effects of 3-ICA may encompass an activity upon the local microbiota composition.
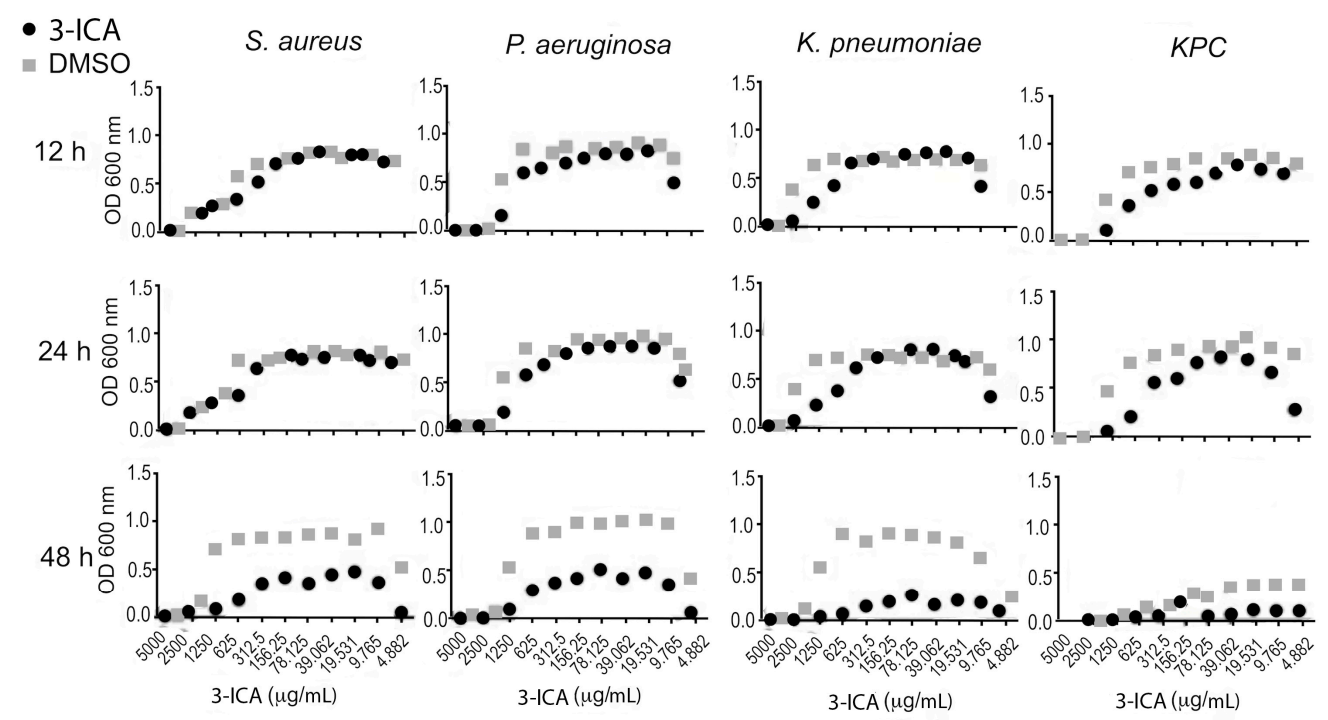

Figure 1. 3-ICA antimicrobial activity in vitro. Bacteria are inoculated into a liquid growth medium in 96-well microtiter plate format in the presence of different concentrations of 3-ICA to determine the minimum inhibitory concentration (unpublished data, see Supplementary Materials).

\subsubsection{3-ICA Ameliorates Respiratory Allergic Bronchopulmonary Aspergillosis}

Recent unpublished research showed that allergic bronchopulmonary aspergillosis (ABPA) could be successfully treated by 3-ICA administration. In fact, 3-ICA intranasal delivery decreased lung immune pathology in ABPA (Figure 2, Supplementary Materials). In particular, 3-ICA administration reduced fungal colonization and eosinophil numbers, mucin production, inflammatory cell influx, and peribronchial fibrosis. Moreover, 3-ICA reduced the Il4 and Il13 gene expression in the lungs, underlining the improvement of the local allergic response to the fungus.

A

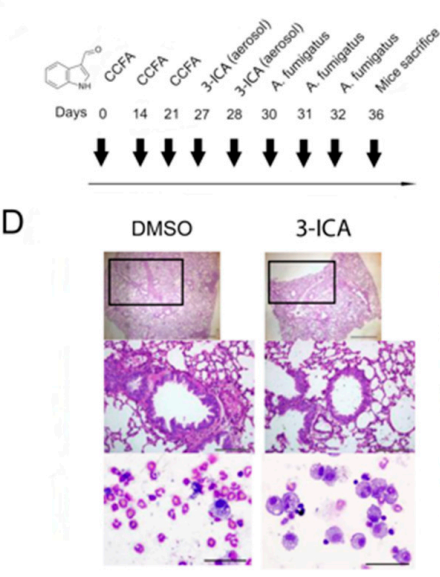

B
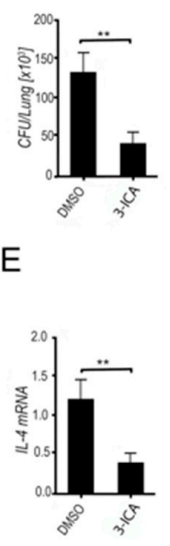

C
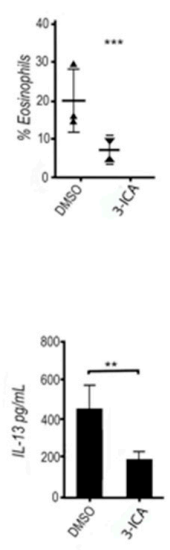

Figure 2. 3-ICA decreases lung immune pathology in ABPA. (A) ABPA mouse model. (B) Fungal growth (CFU, mean $\pm \mathrm{SD}$ ), (C) eosinophil recruitment (\%), and (D) periodic acid Shiff staining of the lungs of C57BL/6 mice with ABPA and treated with 3-ICA (at 7 days post elicitation) or the vehicle DMSO. (E) Il4 and Il33 specific transcripts in the lungs of ABPA mice treated with 3-ICA. ${ }^{* * *} p<0.001$; ** $p<0.001$; unpublished data, see Supplementary Materials). 
The above multiple 3-ICA observed activities, along with the growing knowledge on the AhR importance in restoring microbial eubiosis, immune tolerance, and resistance to pathogens $[179,302]$, underpin a future major role of postbiotics to treat immune and autoimmune diseases as well as bacterial infections [303].

The above findings encourage the development of new nonantibiotic treatments for infectious diseases with a likely tremendous impact on the prevention of AMR. Although as yet to be fully disclosed, even in light of the absence of toxic events, 3-ICA could be proposed as a valid therapeutic alternative for difficult to treat infections.

\section{Conclusions}

On the basis of a metabolic profiling approach, the concept of pharmaco-metabonomic, proposed by Clayton et al. [304], suggests how mining the microbiota may lead to personalized treatment, in which drug-induced responses in individuals can be predicted from a metabolic signature. Indeed, the growing knowledge on the diet-microbiota-host interface fosters opportunities for new therapeutic approaches, based on the selective alteration of microbial metabolite production to support human health and prevent disease. Not only the GM itself may be a largely untapped source of new drugs or lead therapeutic molecules, but also continuous advances will help building novel platforms for the identification and development of new therapeutic strategies for chronic diseases centered on a dual targeting at the host-microbe interface [305,306]. At the same time, detection of microbial metabolites as new sensors will provide new insights into the mechanisms by which the host determines the behavior of the microbial environment, with direct effects on starting inflammation versus keeping homeostasis intact. Moreover, the identification and comprehension of postbiotic mechanisms of action may promote a lead discovery phase of breakthrough therapeutics that centers on correcting the dysfunctional host-pathogen interaction and go beyond the classical mechanisms targeting either the microbes or the host.

Albeit in its infancy, the nonantibiotic strategy to infections shows multiple advantages and may represent a new frontier market for the pharmaceutical industry. The data and considerations reported in this review, although a drop in the sea of knowledge, clearly prove the great potential of this new strategy. What should be minded is that aggressive approaches to infection are tremendously biased, as we are today paying an expensive tribute to decennial mismanagement and careless use of antibiotics. To win our battle against the serious complications of AMR, we need to cope with the overwhelming pathogen capacity to adapt and to develop a very effective defensive arsenal. Therefore, we need to develop the capacity to communicate with the microbes in order to restore a peaceful coexistence that will naturally evolve towards a healthy ecosystem, making eradication unnecessary. Eventually, this new philosophy will surely pay off as it will allow one to prevent the many pathologies associated, not only to infections, but also to the side effects due to the excessive and reckless use of antibiotics. These new opportunities are directly connected to the observed double nature of postbiotics, which act around the host-microbe boundaries. Among all, indoles, in particular 3-ICA, can have a primary role due to their origin and signatures. These compounds possess commercial potential, as they are relatively inexpensive, widely available, and apparently low toxic enabling fast translation to the clinic. In addition, they can be formulated using industrially established technologies. Needless to say, considerable effort is still required in order to fully prove the clinical relevance of most of these compounds. In fact, most studies describing molecular mechanisms of postbiotics have been often performed in vitro or in preclinical settings and their benefits in humans have not been fully elucidated.

Therefore, for the time being, it is not possible to conceive a complete replacement of antibiotic therapies, however a supporting role of postbiotics could be envisaged to improve prevention and control of AMR.

After the first breakthrough discoveries of salvarsan, penicillins, and prontosil antibiotics during the first decades of 1900, due to HDTs and postbiotics, we may now face a second revolution, though requiring a paradigm change in the scientists' way of perceiving infections. Although as yet the end of 
the antibiotic era cannot be conceived, the time when acute or chronic bacterial infections used to be treated with "antibiotic-only" therapies may have come to a blunt end.

Supplementary Materials: The following are available online at http://www.mdpi.com/1999-4923/12/7/624/s1.

Author Contributions: The manuscript was written through contributions of all authors. Conceptualization, S.G., and M.R.; Methodology, M.P., S.X., S.G.; Validation, S.G., M.R. Formal Analysis, M.P. and S.X.; Investigation, M.P., S.G., S.X.; Resources, S.G., M.R.; Writing-Original Draft Preparation, M.P., S.G.; Writing—Review \& Editing, M.P., S.G.; Visualization, S.G., M.R.; Supervision, S.G.; Project Administration, S.G. and M.R.; Funding Acquisition, S.G. All authors have read and agreed to the published version of the manuscript.

Funding: The grant funded to Prof Romani and S.G. by the Italian Cystic Fibrosis Research Foundation (Research Projects number FFC\#24/2018) partially supported this work.

Acknowledgments: The authors wish to acknowledge Luigina Romani for the continuous support in the conduction of in vivo studies.

Conflicts of Interest: The authors declare no competing financial interests.

\section{References}

1. Amann, S.; Neef, K.; Kohl, S. Antimicrobial resistance (AMR). Eur. J. Hosp. Pharm. 2019, 26, $175-177$. [CrossRef] [PubMed]

2. Tacconelli, E.; Sifakis, F.; Harbarth, S.; Schrijver, R.; van Mourik, M.; Voss, A.; Sharland, M.; Rajendran, N.B.; Rodríguez-Baño, J.; Bielicki, J.; et al. Surveillance for control of antimicrobial resistance. Lancet Infect. Dis. 2018, 18, e99-e106. [CrossRef]

3. Jacob, J.T.; Klein, E.; Laxminarayan, R.; Beldavs, Z.; Lynfield, R.; Kallen, A.J.; Ricks, P.; Edwards, J.; Srinivasan, A.; Fridkin, S.; et al. Vital signs: Carbapenem-resistant enterobacteriaceae. Morb. Mortal. Wkly. Rep. 2013, 62, 165-169.

4. Spellberg, B.; Gilbert, D.N. The Future of Antibiotics and Resistance: A Tribute to a Career of Leadership by John Bartlett. Clin. Infect. Dis. 2014, 59, S71-S75. [CrossRef]

5. WHO. Global Antimicrobial Resistance Surveillance System (GLASS) Report: Early Implementation 2020; WHO: Geneva, Switzerland, 2020.

6. Spellberg, B.; Bartlett, J.G.; Gilbert, D.N. The future of antibiotics and resistance. N. Engl. J. Med. 2013, 368, 299-302. [CrossRef]

7. Gould, I.M.; Bal, A.M. New antibiotic agents in the pipeline and how hey can help overcome microbial resistance. Virulence 2013, 4, 185-191. [CrossRef]

8. Murray, A.K. The Novel Coronavirus COVID-19 Outbreak: Global Implications for Antimicrobial Resistance. Front. Microbiol. 2020, 11, 1-4. [CrossRef]

9. AMR Industry Alliance 2020 Progress Report. 2020. Available online: http://www.amrindustryalliance.org/ wp-content/uploads/2020/01/AMR-2020-Progress-Report.pdf (accessed on 25 June 2020).

10. Wang, W.; Arshad, M.I.; Khurshid, M.; Rasool, M.H.; Nisar, M.A.; Aslam, M.A.; Qamar, M.U. Antibiotic resistance: A rundown of a global crisis. Infect. Drug Resist. 2018, 1645-1658.

11. Martens, E.; Demain, A.L. The antibiotic resistance crisis, with a focus on the United States. J. Antibiot. (Tokyo) 2017, 70, 520-526. [CrossRef] [PubMed]

12. The Lancet The antimicrobial crisis: Enough advocacy, more action. Lancet 2020, 395, 247. [CrossRef]

13. Ventola, C.L. The antibiotic resistance crisis: Part 2: Management strategies and new agents. Pharm. Ther. 2015, 40, 344-352.

14. Ventola, C.L. The antibiotic resistance crisis: Causes and threats. Pharm. Ther. J. 2015.

15. Modi, S.R.; Collins, J.J.; Relman, D.A. Antibiotics and the gut microbiota. J. Clin. Investig. 2014, 124, 4212-4218. [CrossRef] [PubMed]

16. Paul, D.; Manna, S.; Mandal, S.M. Antibiotics Associated Disorders and Post-biotics Induced Rescue in Gut Health. Curr. Pharm. Des. 2017, 24, 821-829. [CrossRef] [PubMed]

17. Grigg, J.B.; Sonnenberg, G.F. Host-Microbiota Interactions Shape Local and Systemic Inflammatory Diseases. J. Immunol. 2017, 198, 564-571. [CrossRef] [PubMed]

18. Li, X.V.; Leonardi, I.; Iliev, I.D. Gut Mycobiota in Immunity and Inflammatory Disease. Immunity 2019, 50, 1365-1379. [CrossRef] [PubMed] 
19. Francino, M.P. Antibiotics and the Human Gut Microbiome: Dysbioses and Accumulation of Resistances. Front. Microbiol. 2016, 6. [CrossRef] [PubMed]

20. Chan, B.K.; Abedon, S.T.; Loc-Carrillo, C. Phage cocktails and the future of phage therapy. Future Microbiol. 2013, 8, 769-783. [CrossRef] [PubMed]

21. Tagliabue, A.; Rappuoli, R. Changing Priorities in Vaccinology: Antibiotic Resistance Moving to the Top. Front. Immunol. 2018, 9. [CrossRef]

22. Abedon, S.T. Phage therapy of pulmonary infections. Bacteriophage 2015, 5, e1020260. [CrossRef] [PubMed]

23. Yasuyuki, M.; Kunihiro, K.; Kurissery, S.; Kanavillil, N.; Sato, Y.; Kikuchi, Y. Antibacterial properties of nine pure metals: A laboratory study using Staphylococcus aureus and Escherichia coli. Biofouling 2010, 26, 851-858. [CrossRef] [PubMed]

24. Beloin, C.; Renard, S.; Ghigo, J.-M.; Lebeaux, D. Novel approaches to combat bacterial biofilms. Curr. Opin. Pharmacol. 2014, 18, 61-68. [CrossRef] [PubMed]

25. Krachler, A.M.; Orth, K. Targeting the bacteria-host interface strategies in anti-adhesion therapy. Virulence 2013, 4, 284-294. [CrossRef] [PubMed]

26. DeFilipp, Z.; Bloom, P.P.; Soto, M.T.; Mansour, M.K.; Sater, M.R.A.; Huntley, M.H.; Turbett, S.; Chung, R.T.; Chen, Y.B.; Hohmann, E.L. Drug-resistant e. coli bacteremia transmitted by fecal microbiota transplant. N. Engl. J. Med. 2019, 381, 2043-2050. [CrossRef]

27. Nielsen, T.B.; Brass, E.P.; Gilbert, D.N.; Bartlett, J.G.; Spellberg, B. Sustainable discovery and development of antibiotics - Is a nonprofit approach the future? N. Engl. J. Med. 2019, 381, 503-505. [CrossRef]

28. Diel, R. Treatment of tuberculosis. Pneumologe 2019, 16, 117-130. [CrossRef]

29. Kaufmann, S.H.E.; Dorhoi, A.; Hotchkiss, R.S.; Bartenschlager, R. Host-directed therapies for bacterial and viral infections. Nat. Rev. Drug Discov. 2018, 17, 35-56. [CrossRef]

30. Andersson, J.A.; Sha, J.; Kirtley, M.L.; Reyes, E.; Fitts, E.C.; Dann, S.M.; Chopra, A.K. Combating Multidrug-Resistant Pathogens with Host-Directed Nonantibiotic Therapeutics. Antimicrob. Agents Chemother. 2017, 62. [CrossRef]

31. Terme, M.; Ullrich, E.; Delahaye, N.F.; Chaput, N.; Zitvogel, L. Natural killer cell-directed therapies: Moving from unexpected results to successful strategies. Nat. Immunol. 2008, 9, 486-494. [CrossRef]

32. Ulevitch, R.J. Therapeutics targeting the innate immune system. Nat. Rev. Immunol. 2004, 4, 512-520. [CrossRef]

33. Montoya, D.; Inkeles, M.S.; Liu, P.T.; Realegeno, S.; Teles, R.M.B.; Vaidya, P.; Munoz, M.A.; Schenk, M.; Swindell, W.R.; Chun, R.; et al. IL-32 is a molecular marker of a host defense network in human tuberculosis. Sci. Transl. Med. 2014, 6, 250ra114. [CrossRef] [PubMed]

34. Wallis, R.S.; van Vuuren, C.; Potgieter, S. Adalimumab Treatment of Life-Threatening Tuberculosis. Clin. Infect. Dis. 2009, 48, 1429-1432. [CrossRef] [PubMed]

35. Phillips, B.L.; Mehra, S.; Ahsan, M.H.; Selman, M.; Khader, S.A.; Kaushal, D. LAG3 Expression in Active Mycobacterium tuberculosis Infections. Am. J. Pathol. 2015, 185, 820-833. [CrossRef] [PubMed]

36. Skrahin, A.; Ahmed, R.K.; Ferrara, G.; Rane, L.; Poiret, T.; Isaikina, Y.; Skrahina, A.; Zumla, A.; Maeurer, M.J. Autologous mesenchymal stromal cell infusion as adjunct treatment in patients with multidrug and extensively drug-resistant tuberculosis: An open-label phase 1 safety trial. Lancet Respir. Med. 2014, 2, 108-122. [CrossRef]

37. Paik, S.; Kim, J.K.; Chung, C.; Jo, E.K. Autophagy: A new strategy for host-directed therapy of tuberculosis. Virulence 2019, 10, 448-459. [CrossRef]

38. Atkin, T.A.; Maher, C.M.; Gerlach, A.C.; Gay, B.C.; Antonio, B.M.; Santos, S.C.; Padilla, K.M.; Rader, J.A.; Krafte, D.S.; Fox, M.A.; et al. A comprehensive approach to identifying repurposed drugs to treat SCN8A epilepsy. Epilepsia 2018, 59, 802-813. [CrossRef]

39. Tharmalingam, N.; Port, J.; Castillo, D.; Mylonakis, E. Repurposing the anthelmintic drug niclosamide to combat Helicobacter pylori. Sci. Rep. 2018, 8, 1-12. [CrossRef]

40. Abdelaleem, M.; Ezzat, H.; Osama, M.; Megahed, A.; Alaa, W.; Gaber, A.; Shafei, A.; Refaat, A. Prospects for repurposing CNS drugs for cancer treatment. Oncol. Rev. 2019, 13, 37-42. [CrossRef]

41. Tobin, D.M.; Roca, F.J.; Ray, J.P.; Ko, D.C.; Ramakrishnan, L. An Enzyme That Inactivates the Inflammatory Mediator Leukotriene B4 Restricts Mycobacterial Infection. PLoS ONE 2013, 8, e67828. [CrossRef] 
42. Vilaplana, C.; Marzo, E.; Tapia, G.; Diaz, J.; Garcia, V.; Cardona, P.J. Ibuprofen therapy resulted in significantly decreased tissue bacillary loads and increased survival in a new murine experimental model of active tuberculosis. J. Infect. Dis. 2013, 208, 199-202. [CrossRef]

43. Ivanyi, J.; Zumla, A. Nonsteroidal Antiinflammatory Drugs for Adjunctive Tuberculosis Treatment. J. Infect. Dis. 2013, 208, 185-188. [CrossRef] [PubMed]

44. Blum, C.A.; Nigro, N.; Briel, M.; Schuetz, P.; Ullmer, E.; Suter-Widmer, I.; Winzeler, B.; Bingisser, R.; Elsaesser, H.; Drozdov, D.; et al. Adjunct prednisone therapy for patients with community-acquired pneumonia: A multicentre, double-blind, randomised, placebo-controlled trial. Lancet 2015, 385, 1511-1518. [CrossRef]

45. Ferrer, M.; Torres, A.; Baer, R.; Hernández, C.; Roca, J.; Rodriguez-Roisin, R. Effect of Acetylsalicylic Acid on Pulmonary Gas Exchange in Patients With Severe Pneumonia. Chest 1997, 111, 1094-1100. [CrossRef]

46. Bernard, G.R.; Wheeler, A.P.; Russell, J.A.; Schein, R.; Summer, W.R.; Steinberg, K.P.; Fulkerson, W.J.; Wright, P.E.; Christman, B.W.; Dupont, W.D.; et al. The Effects of Ibuprofen on the Physiology and Survival of Patients with Sepsis. N. Engl. J. Med. 1997, 336, 912-918. [CrossRef]

47. Halperin, S.A.; Vaudry, W.; Boucher, F.D.; Mackintosh, K.; Waggener, T.B.; Smith, B. Is pertussis immune globulin efficacious for the treatment of hospitalized infants with pertussis? No answer yet. Pediatr. Infect. Dis. J. 2007, 26, 79-81. [CrossRef]

48. Bruss, J.B.; Siber, G.R. Protective effects of pertussis immunoglobulin (P-IGIV) in the aerosol challenge model. Clin. Diagn. Lab. Immunol. 1999, 6, 464-470. [CrossRef] [PubMed]

49. Scanlon, K.M.; Skerry, C.; Carbonetti, N.H. Novel therapies for the treatment of pertussis disease. Pathog. Dis. 2015, 73, ftv074. [CrossRef]

50. Koh, G.C.K.W.; Weehuizen, T.A.; Breitbach, K.; Krause, K.; de Jong, H.K.; Kager, L.M.; Hoogendijk, A.J.; Bast, A.; Peacock, S.J.; van der Poll, T.; et al. Glyburide Reduces Bacterial Dissemination in a Mouse Model of Melioidosis. PLoS Negl. Trop. Dis. 2013, 7, e2500. [CrossRef]

51. Skerry, C.; Scanlon, K.; Rosen, H.; Carbonetti, N.H. Sphingosine-1-phosphate Receptor Agonism Reduces Bordetella pertussis- mediated Lung Pathology. J. Infect. Dis. 2015, 211, 1883-1886. [CrossRef]

52. Döcke, W.D.; Randow, F.; Syrbe, U.; Krausch, D.; Asadullah, K.; Reinke, P.; Volk, H.D.; Kox, W. Monocyte deactivation in septic patients: Restoration by IFN- $\gamma$ treatment. Nat. Med. 1997, 3, 678-681. [CrossRef]

53. Rosenbloom, A.J.; Linden, P.K.; Dorrance, A.; Penkosky, N.; Cohen-Melamed, M.H.; Pinsky, M.R. Effect of granulocyte-monocyte colony-stimulating factor therapy on leukocyte function and clearance of serious infection in nonneutropenic patients. Chest 2005, 127, 2139-2150. [CrossRef] [PubMed]

54. Presneill, J.J.; Harris, T.; Stewart, A.G.; Cade, J.F.; Wilson, J.W. A randomized phase II trial of granulocyte-macrophage colony-stimulating factor therapy in severe sepsis with respiratory dysfunction. Am. J. Respir. Crit. Care Med. 2002, 166, 138-143. [CrossRef] [PubMed]

55. Steinmann, J.; Halldórsson, S.; Agerberth, B.; Gudmundsson, G.H. Phenylbutyrate induces antimicrobial peptide expression. Antimicrob. Agents Chemother. 2009, 53, 5127-5133. [CrossRef]

56. Wang, T.-T.; Nestel, F.P.; Bourdeau, V.; Nagai, Y.; Wang, Q.; Liao, J.; Tavera-Mendoza, L.; Lin, R.; Hanrahan, J.W.; Mader, S.; et al. Cutting Edge: 1,25-Dihydroxyvitamin D 3 Is a Direct Inducer of Antimicrobial Peptide Gene Expression. J. Immunol. 2004, 173, 2909-2912. [CrossRef]

57. Gombart, A.F.; Borregaard, N.; Koeffler, H.P. Human cathelicidin antimicrobial peptide (CAMP) gene is a direct target of the vitamin $\mathrm{D}$ receptor and is strongly up-regulated in myeloid cells by 1,25-dihydroxyvitamin D 3. FASEB J. 2005, 19, 1067-1077. [CrossRef] [PubMed]

58. Sechet, E.; Telford, E.; Bonamy, C.; Sansonetti, P.J.; Sperandio, B. Natural molecules induce and synergize to boost expression of the human antimicrobial peptide $\beta$-defensin-3. Proc. Natl. Acad. Sci. USA 2018, 115, E9869-E9878. [CrossRef] [PubMed]

59. Barber, D.L.; Sakai, S.; Kudchadkar, R.R.; Fling, S.P.; Day, T.A.; Vergara, J.A.; Ashkin, D.; Cheng, J.H.; Lundgren, L.M.; Raabe, V.N.; et al. Tuberculosis following PD-1 blockade for cancer immunotherapy. Sci. Transl. Med. 2019, 11.

60. Munguia, J.; Nizet, V. Pharmacological Targeting of the Host-Pathogen Interaction: Alternatives to Classical Antibiotics to Combat Drug-Resistant Superbugs. Trends Pharmacol. Sci. 2017, 38, 473-488. [CrossRef]

61. Roduit, C.; Scholtens, S.; De Jongste, J.C.; Wijga, A.H.; Gerritsen, J.; Postma, D.S.; Brunekreef, B.; Hoekstra, M.O.; Aalberse, R.; Smit, H.A. Asthma at 8 years of age in children born by caesarean section. Thorax 2009, 64, 107-113. [CrossRef] 
62. Mårild, K.; Ye, W.; Lebwohl, B.; Green, P.H.R.; Blaser, M.J.; Card, T.; Ludvigsson, J.F. Antibiotic exposure and the development of coeliac disease: A nationwide case-control study. BMC Gastroenterol. 2013, 13, 109. [CrossRef]

63. Watson, J.; Jones, R.C.; Cortes, C.; Gerber, S.I.; Golash, R.G.; Price, J.; Bancroft, E.; Mascola, L.; Gorwitz, R.J.; Jernigan, D.B.; et al. Community-associated methicillin-resistant Staphylococcus aureus infection among healthy newborns - Chicago and Los Angeles County, 2004. Morb. Mortal. Wkly. Rep. 2006, 55, 329-332.

64. Sekirov, I.; Tam, N.M.; Jogova, M.; Robertson, M.L.; Li, Y.; Lupp, C.; Finlay, B.B. Antibiotic-induced perturbations of the intestinal microbiota alter host susceptibility to enteric infection. Infect. Immun. 2008, 76, 4726-4736. [CrossRef] [PubMed]

65. Chang, J.Y.; Antonopoulos, D.A.; Kalra, A.; Tonelli, A.; Khalife, W.T.; Schmidt, T.M.; Young, V.B. Decreased Diversity of the Fecal Microbiome in Recurrent Clostridium difficile-Associated Diarrhea. J. Infect. Dis. 2008, 197, 435-438. [CrossRef]

66. Buffie, C.G.; Jarchum, I.; Equinda, M.; Lipuma, L.; Gobourne, A.; Viale, A.; Ubeda, C.; Xavier, J.; Pamer, E.G. Profound alterations of intestinal microbiota following a single dose of clindamycin results in sustained susceptibility to Clostridium difficile-induced colitis. Infect. Immun. 2012, 80, 62-73. [CrossRef]

67. Clemente, J.C.; Ursell, L.K.; Parfrey, L.W.; Knight, R. The impact of the gut microbiota on human health: An integrative view. Cell 2012, 148, 1258-1270. [CrossRef] [PubMed]

68. Fessler, J.; Matson, V.; Gajewski, T.F. Exploring the emerging role of the microbiome in cancer immunotherapy. J. Immunother. Cancer 2019, 7, 108. [CrossRef]

69. Taylor, V.H. The microbiome and mental health: Hope or hype? J. Psychiatry Neurosci. 2019, 44, $219-222$. [CrossRef]

70. Thaiss, C.A.; Elinav, E. The remedy within: Will the microbiome fulfill its therapeutic promise? J. Mol. Med. 2017, 95, 1021-1027. [CrossRef]

71. Human Microbiome Project Consortium Structure, function and diversity of the healthy human microbiome. Nature 2012, 486, 207-214. [CrossRef]

72. Simon, G.L.; Gorbach, S.L. Intestinal flora in health and disease. Gastroenterology 1984, 86, 174-193. [CrossRef]

73. Delhaes, L.; Monchy, S.; Fréalle, E.; Hubans, C.; Salleron, J.; Leroy, S.; Prevotat, A.; Wallet, F.; Wallaert, B.; Dei-Cas, E.; et al. The Airway Microbiota in Cystic Fibrosis: A Complex Fungal and Bacterial Community-Implications for Therapeutic Management. PLoS ONE 2012, 7, e36313. [CrossRef] [PubMed]

74. Ott, S.J.; Kühbacher, T.; Musfeldt, M.; Rosenstiel, P.; Hellmig, S.; Rehman, A.; Drews, O.; Weichert, W.; Timmis, K.N.; Schreiber, S. Fungi and inflammatory bowel diseases: Alterations of composition and diversity. Scand. J. Gastroenterol. 2008, 43, 831-841. [CrossRef] [PubMed]

75. Li, Q.; Wang, C.; Tang, C.; He, Q.; Li, N.; Li, J. Dysbiosis of gut fungal microbiota is associated with mucosal inflammation in crohn's disease. J. Clin. Gastroenterol. 2014, 48, 513-523. [CrossRef]

76. Hoffmann, C.; Dollive, S.; Grunberg, S.; Chen, J.; Li, H.; Wu, G.D.; Lewis, J.D.; Bushman, F.D. Archaea and Fungi of the Human Gut Microbiome: Correlations with Diet and Bacterial Residents. PLoS ONE 2013, 8, e66019. [CrossRef] [PubMed]

77. Zhang, E.; Tanaka, T.; Tajima, M.; Tsuboi, R.; Nishikawa, A.; Sugita, T. Characterization of the skin fungal microbiota in patients with atopic dermatitis and in healthy subjects. Microbiol. Immunol. 2011, 55, 625-632. [CrossRef] [PubMed]

78. Smeekens, S.P.; Malireddi, R.K.; Plantinga, T.S.; Buffen, K.; Oosting, M.; Joosten, L.A.B.; Kullberg, B.J.; Perfect, J.R.; Scott, W.K.; Van De Veerdonk, F.L.; et al. Autophagy is redundant for the host defense against systemic Candida albicans infections. Eur. J. Clin. Microbiol. Infect. Dis. 2014, 33, 711-722. [CrossRef]

79. Cully, M. Antibiotics alter the gut microbiome and host health. Nat. Milestones 2019, 1423, S19.

80. Lavelle, A.; Hoffmann, T.W.; Pham, H.P.; Langella, P.; Guédon, E.; Sokol, H. Baseline microbiota composition modulates antibiotic-mediated effects on the gut microbiota and host. Microbiome 2019, 7, 111. [CrossRef]

81. Bhalodi, A.A.; Van Engelen, T.S.R.; Virk, H.S.; Wiersinga, W.J. Impact of antimicrobial therapy on the gut microbiome. J. Antimicrob. Chemother. 2019, 74, I6-I15. [CrossRef]

82. Baümler, A.J.; Sperandio, V. Interactions between the microbiota and pathogenic bacteria in the gut. Nature 2016, 535, 85-93. [CrossRef]

83. Becattini, S.; Taur, Y.; Pamer, E.G. Antibiotic-Induced Changes in the Intestinal Microbiota and Disease. Trends Mol. Med. 2016, 22, 458-478. [CrossRef] [PubMed] 
84. Zhang, S.; Chen, D.C.; Chen, L.M. Facing a new challenge: The adverse effects of antibiotics on gut microbiota and host immunity. Chin. Med. J. (Engl.) 2019, 132, 1135-1138. [CrossRef] [PubMed]

85. Guarner, F.; Malagelada, J.R. Gut flora in health and disease. Lancet 2003, 361, 512-519. [CrossRef]

86. Stefka, A.T.; Feehley, T.; Tripathi, P.; Qiu, J.; McCoy, K.; Mazmanian, S.K.; Tjota, M.Y.; Seo, G.Y.; Cao, S.; Theriault, B.R.; et al. Commensal bacteria protect against food allergen sensitization. Proc. Natl. Acad. Sci. USA 2014, 111, 13145-13150. [CrossRef] [PubMed]

87. Hsiao, E.Y.; McBride, S.W.; Hsien, S.; Sharon, G.; Hyde, E.R.; McCue, T.; Codelli, J.A.; Chow, J.; Reisman, S.E.; Petrosino, J.F.; et al. Microbiota modulate behavioral and physiological abnormalities associated with neurodevelopmental disorders. Cell 2013, 155, 1451-1463. [CrossRef] [PubMed]

88. Teo, S.M.; Mok, D.; Pham, K.; Kusel, M.; Serralha, M.; Troy, N.; Holt, B.J.; Hales, B.J.; Walker, M.L.; Hollams, E.; et al. The infant nasopharyngeal microbiome impacts severity of lower respiratory infection and risk of asthma development. Cell Host Microbe 2015, 17, 704-715. [CrossRef]

89. Cuthbertson, L.; Rogers, G.B.; Walker, A.W.; Oliver, A.; Green, L.E.; Daniels, T.W.V.; Carroll, M.P.; Parkhill, J.; Bruce, K.D.; Van Der Gast, C.J. Respiratory microbiota resistance and resilience to pulmonary exacerbation and subsequent antimicrobial intervention. ISME J. 2016, 10, 1081-1091. [CrossRef]

90. Dedrick, R.M.; Guerrero-Bustamante, C.A.; Garlena, R.A.; Russell, D.A.; Ford, K.; Harris, K.; Gilmour, K.C.; Soothill, J.; Jacobs-Sera, D.; Schooley, R.T.; et al. Engineered bacteriophages for treatment of a patient with a disseminated drug-resistant Mycobacterium abscessus. Nat. Med. 2019, 25, 730-733. [CrossRef]

91. Chan, B.K.; Turner, P.E.; Kim, S.; Mojibian, H.R.; Elefteriades, J.A.; Narayan, D. Phage treatment of an aortic graft infected with Pseudomonas aeruginosa. Evol. Med. Public Heal. 2018, 2018, 60-66. [CrossRef]

92. Jault, P.; Leclerc, T.; Jennes, S.; Pirnay, J.P.; Que, Y.A.; Resch, G.; Rousseau, A.F.; Ravat, F.; Carsin, H.; Le Floch, R.; et al. Efficacy and tolerability of a cocktail of bacteriophages to treat burn wounds infected by Pseudomonas aeruginosa (PhagoBurn): A randomised, controlled, double-blind phase 1/2 trial. Lancet Infect. Dis. 2019, 19, 35-45. [CrossRef]

93. Vahedi, A.; Soltan Dallal, M.M.; Douraghi, M.; Nikkhahi, F.; Rajabi, Z.; Yousefi, M.; Mousavi, M. Isolation and identification of specific bacteriophage against enteropathogenic Escherichia coli (EPEC) and in vitro and in vivo characterization of bacteriophage. FEMS Microbiol. Lett. 2018, 365. [CrossRef]

94. Chadha, P.; Katare, O.P.; Chhibber, S. Liposome loaded phage cocktail: Enhanced therapeutic potential in resolving Klebsiella pneumoniae mediated burn wound infections. Burns 2017, 43, 1532-1543. [CrossRef] [PubMed]

95. Murphy, C.L.; Zulquernain, S.A.; Shanahan, F. Faecal Microbiota Transplantation (FMT)—Classical bedside-to-bench clinical research. QJM 2019, 112. [CrossRef]

96. Paramsothy, S.; Kamm, M.A.; Kaakoush, N.O.; Walsh, A.J.; van den Bogaerde, J.; Samuel, D.; Leong, R.W.L.; Connor, S.; Ng, W.; Paramsothy, R.; et al. Multidonor intensive faecal microbiota transplantation for active ulcerative colitis: A randomised placebo-controlled trial. Lancet 2017, 389, 1218-1228. [CrossRef]

97. Paramsothy, S.; Paramsothy, R.; Rubin, D.T.; Kamm, M.A.; Kaakoush, N.O.; Mitchell, H.M.; Castaño-Rodríguez, N. Faecal Microbiota Transplantation for Inflammatory Bowel Disease: A Systematic Review and Meta-analysis. J. Crohn's Colitis 2017, 11, 1180-1199. [CrossRef] [PubMed]

98. Islam, S.U. Clinical Uses of Probiotics. Medicine (Baltimore) 2016, 95, e2658. [CrossRef]

99. Kim, H.G.; Lee, S.Y.; Kim, N.R.; Lee, H.Y.; Ko, M.Y.; Jung, B.J.; Kim, C.M.; Lee, J.M.; Park, J.H.; Han, S.H.; et al. Lactobacillus plantarum lipoteichoic acid down-regulated Shigella flexneri peptidoglycan-induced inflammation. Mol. Immunol. 2011, 48, 382-391. [CrossRef]

100. Sokol, H.; Pigneur, B.; Watterlot, L.; Lakhdari, O.; Bermudez-Humaran, L.G.; Gratadoux, J.-J.; Blugeon, S.; Bridonneau, C.; Furet, J.-P.; Corthier, G.; et al. Faecalibacterium prausnitzii is an anti-inflammatory commensal bacterium identified by gut microbiota analysis of Crohn disease patients. Proc. Natl. Acad. Sci. USA 2008, 105, 16731-16736. [CrossRef]

101. Hart, A.L.; Stagg, A.J.; Kamm, M.A. Use of Probiotics in the Treatment of Inflammatory Bowel Disease. J. Clin. Gastroenterol. 2003, 36, 111-119. [CrossRef]

102. Stripling, J.; Kumar, R.; Baddley, J.W.; Nellore, A.; Dixon, P.; Howard, D.; Ptacek, T.; Lefkowitz, E.J.; Tallaj, J.A.; Benjamin, W.H.; et al. Loss of Vancomycin-Resistant Enterococcus Fecal Dominance in an Organ Transplant Patient With Clostridium difficile Colitis After Fecal Microbiota Transplant. Open Forum Infect. Dis. 2015, 2. [CrossRef] 
103. Cammarota, G.; Masucci, L.; Ianiro, G.; Bibbò, S.; Dinoi, G.; Costamagna, G.; Sanguinetti, M.; Gasbarrini, A. Randomised clinical trial: Faecal microbiota transplantation by colonoscopy vs. vancomycin for the treatment of recurrent Clostridium difficile infection. Aliment. Pharmacol. Ther. 2015, 41, 835-843. [CrossRef]

104. Battipaglia, G.; Malard, F.; Rubio, M.T.; Ruggeri, A.; Mamez, A.C.; Brissot, E.; Giannotti, F.; Dulery, R.; Joly, A.C.; Baylatry, M.T.; et al. Fecal microbiota transplantation before or after allogeneic hematopoietic transplantation in patients with hematologic malignancies carrying multidrug-resistance bacteria. Haematologica 2019, 104, 1682-1688. [CrossRef] [PubMed]

105. Ganeshan, S.D.; Hosseinidoust, Z. Phage therapy with a focus on the human microbiota. Antibiotics 2019, 8 , 131. [CrossRef] [PubMed]

106. Sutton, T.D.S.; Hill, C. Gut Bacteriophage: Current Understanding and Challenges. Front. Endocrinol. (Lausanne) 2019. [CrossRef] [PubMed]

107. Hsu, B.B.; Gibson, T.E.; Yeliseyev, V.; Liu, Q.; Lyon, L.; Bry, L.; Silver, P.A.; Gerber, G.K. Dynamic Modulation of the Gut Microbiota and Metabolome by Bacteriophages in a Mouse Model. Cell Host Microbe 2019, 25, 803-814.e5. [CrossRef]

108. Paule, A.; Frezza, D.; Edeas, M. Microbiota and Phage Therapy: Future Challenges in Medicine. Med. Sci. 2018, 6, 86. [CrossRef]

109. Sausset, R.; Petit, M.A.; Gaboriau-Routhiau, V.; De Paepe, M. New insights into intestinal phages. Mucosal Immunol. 2020. [CrossRef]

110. Wong, W.F.; Santiago, M. Microbial approaches for targeting antibiotic-resistant bacteria. Microb. Biotechnol. 2017, 10, 1047-1053. [CrossRef]

111. Tkhilaishvili, T.; Lombardi, L.; Klatt, A.B.; Trampuz, A.; Di Luca, M. Bacteriophage Sb-1 enhances antibiotic activity against biofilm, degrades exopolysaccharide matrix and targets persisters of Staphylococcus aureus. Int. J. Antimicrob. Agents 2018, 52, 842-853. [CrossRef]

112. Fong, S.A.; Drilling, A.; Morales, S.; Cornet, M.E.; Woodworth, B.A.; Fokkens, W.J.; Psaltis, A.J.; Vreugde, S.; Wormald, P.-J. Activity of Bacteriophages in Removing Biofilms of Pseudomonas aeruginosa Isolates from Chronic Rhinosinusitis Patients. Front. Cell. Infect. Microbiol. 2017, 7. [CrossRef]

113. Bourdin, G.; Navarro, A.; Sarker, S.A.; Pittet, A.-C.; Qadri, F.; Sultana, S.; Cravioto, A.; Talukder, K.A.; Reuteler, G.; Brüssow, H. Coverage of diarrhoea-associated E scherichia coli isolates from different origins with two types of phage cocktails. Microb. Biotechnol. 2014, 7, 165-176. [CrossRef] [PubMed]

114. Maciejewska, B.; Olszak, T.; Drulis-Kawa, Z. Applications of bacteriophages versus phage enzymes to combat and cure bacterial infections: An ambitious and also a realistic application? Appl. Microbiol. Biotechnol. 2018, 102, 2563-2581. [CrossRef] [PubMed]

115. Furfaro, L.L.; Payne, M.S.; Chang, B.J. Bacteriophage Therapy: Clinical Trials and Regulatory Hurdles. Front. Cell. Infect. Microbiol. 2018, 8, 376. [CrossRef]

116. Pirnay, J.P.; Verbeken, G.; Ceyssens, P.J.; Huys, I.; de Vos, D.; Ameloot, C.; Fauconnier, A. The magistral phage. Viruses 2018, 10, 64. [CrossRef]

117. Lerner, A.; Matthias, T.; Aminov, R. Potential effects of horizontal gene exchange in the human gut. Front. Immunol. 2017, 8, 1630. [CrossRef]

118. Wong, A.; Ngu, D.Y.S.; Dan, L.A.; Ooi, A.; Lim, R.L.H. Detection of antibiotic resistance in probiotics of dietary supplements. Nutr. J. 2015, 14, 95. [CrossRef]

119. Lerner, A.; Matthias, T. Changes in intestinal tight junction permeability associated with industrial food additives explain the rising incidence of autoimmune disease. Autoimmun. Rev. 2015, 14, 479-489. [CrossRef]

120. Lerner, A.; Aminov, R.; Matthias, T. Transglutaminases in Dysbiosis As Potential Environmental Drivers of Autoimmunity. Front. Microbiol. 2017, 8. [CrossRef]

121. Matthias, T.; Jeremias, P.; Neidhöfer, S.; Lerner, A. The industrial food additive, microbial transglutaminase, mimics tissue transglutaminase and is immunogenic in celiac disease patients. Autoimmun. Rev. 2016, 15, 1111-1119. [CrossRef]

122. Torsten, M.; Aaron, L. Microbial Transglutaminase Is Immunogenic and Potentially Pathogenic in Pediatric Celiac Disease. Front. Pediatr. 2018, 6. [CrossRef]

123. Singh, A.; Sarangi, A.N.; Goel, A.; Srivastava, R.; Bhargava, R.; Gaur, P.; Aggarwal, A.; Aggarwal, R. Effect of administration of a probiotic preparation on gut microbiota and immune response in healthy women in India: An open-label, single-arm pilot study. BMC Gastroenterol. 2018, 18, 85. [CrossRef] 
124. Laursen, M.F.; Laursen, R.P.; Larnkjær, A.; Michaelsen, K.F.; Bahl, M.I.; Licht, T.R. Administration of two probiotic strains during early childhood does not affect the endogenous gut microbiota composition despite probiotic proliferation. BMC Microbiol. 2017, 17, 175. [CrossRef] [PubMed]

125. Kristensen, N.B.; Bryrup, T.; Allin, K.H.; Nielsen, T.; Hansen, T.H.; Pedersen, O. Alterations in fecal microbiota composition by probiotic supplementation in healthy adults: A systematic review of randomized controlled trials. Genome Med. 2016, 8, 52. [CrossRef] [PubMed]

126. Muñoz, J.A.M.; Chenoll, E.; Casinos, B.; Bataller, E.; Ramón, D.; Genovés, S.; Montava, R.; Ribes, J.M.; Buesa, J.; Fàbrega, J.; et al. Novel probiotic Bifidobacterium longum subsp. infantis CECT 7210 strain active against rotavirus infections. Appl. Environ. Microbiol. 2011, 77, 8775-8783. [CrossRef] [PubMed]

127. Jalali, M.; Abedi, D.; Varshosaz, J.; Najjarzadeh, M.; Mirlohi, M.; Tavakoli, N. Stability evaluation of freeze-dried Lactobacillus paracasei subsp. tolerance and Lactobacillus delbrueckii subsp. bulgaricus in oral capsules. Res. Pharm. Sci. 2012, 7, 31-36.

128. Markowiak, P.; Ślizewska, K. Effects of Probiotics, Prebiotics, and Synbiotics on Human Health. Nutrients 2017, 9, 1021. [CrossRef] [PubMed]

129. Pandey, K.R.; Naik, S.R.; Vakil, B.V. Probiotics, prebiotics and synbiotics-A review. J. Food Sci. Technol. 2015, 52, 7577-7587. [CrossRef]

130. McFarland, L.V.; Goh, S. Are probiotics and prebiotics effective in the prevention of travellers' diarrhea: A systematic review and meta-analysis. Travel Med. Infect. Dis. 2019, 27, 11-19. [CrossRef] [PubMed]

131. Jin, L.; Deng, L.; Wu, W.; Wang, Z.; Shao, W.; Liu, J. Systematic review and meta-analysis of the effect of probiotic supplementation on functional constipation in children. Medicine (USA) 2018, 97, e12174. [CrossRef]

132. Rouhani, M.H.; Hadi, A.; Ghaedi, E.; Salehi, M.; Mahdavi, A.; Mohammadi, H. Do probiotics, prebiotics and synbiotics affect adiponectin and leptin in adults? A systematic review and meta-analysis of clinical trials. Clin. Nutr. 2019, 38, 2031-2037. [CrossRef]

133. Tan-Lim, C.S.C.; Esteban-Ipac, N.A.R. Probiotics as treatment for food allergies among pediatric patients: A meta-analysis. World Allergy Organ. J. 2018, 11, 25. [CrossRef] [PubMed]

134. Upadhyay, R.P.; Taneja, S.; Chowdhury, R.; Strand, T.A.; Bhandari, N. Effect of prebiotic and probiotic supplementation on neurodevelopment in preterm very low birth weight infants: Findings from a meta-analysis. Pediatr. Res. 2018. [CrossRef]

135. Aqaeinezhad Rudbane, S.M.; Rahmdel, S.; Abdollahzadeh, S.M.; Zare, M.; Bazrafshan, A.; Mazloomi, S.M. The efficacy of probiotic supplementation in rheumatoid arthritis: A meta-analysis of randomized, controlled trials. Inflammopharmacology 2018, 26, 67-76. [CrossRef] [PubMed]

136. Hassan, H.; Rompola, M.; Glaser, A.W.; Kinsey, S.E.; Phillips, R.S. Systematic review and meta-analysis investigating the efficacy and safety of probiotics in people with cancer. Support. Care Cancer 2018, 26, 2503-2509. [CrossRef]

137. Vieira, A.T.; Fukumori, C.; Ferreira, C.M. New insights into therapeutic strategies for gut microbiota modulation in inflammatory diseases. Clin. Transl. Immunol. 2016, 5, e87. [CrossRef] [PubMed]

138. Descamps, H.C.; Herrmann, B.; Wiredu, D.; Thaiss, C.A. The path toward using microbial metabolites as therapies. EBioMedicine 2019, 44,747-754. [CrossRef]

139. Klemashevich, C.; Wu, C.; Howsmon, D.; Alaniz, R.C.; Lee, K.; Jayaraman, A. Rational identification of diet-derived postbiotics for improving intestinal microbiota function. Curr. Opin. Biotechnol. 2014, 26, 85-90. [CrossRef]

140. Shoaie, S.; Ghaffari, P.; Kovatcheva-Datchary, P.; Mardinoglu, A.; Sen, P.; Pujos-Guillot, E.; De Wouters, T.; Juste, C.; Rizkalla, S.; Chilloux, J.; et al. Quantifying Diet-Induced Metabolic Changes of the Human Gut Microbiome. Cell Metab. 2015, 22, 320-331. [CrossRef] [PubMed]

141. Zeevi, D.; Korem, T.; Zmora, N.; Israeli, D.; Rothschild, D.; Weinberger, A.; Ben-Yacov, O.; Lador, D.; Avnit-Sagi, T.; Lotan-Pompan, M.; et al. Personalized Nutrition by Prediction of Glycemic Responses. Cell 2015, 163, 1079-1094. [CrossRef]

142. Umu, Ö.C.O.; Rudi, K.; Diep, D.B. Modulation of the gut microbiota by prebiotic fibres and bacteriocins. Microb. Ecol. Health Dis. 2017, 28, 1348886. [CrossRef]

143. Wikoff, W.R.; Anfora, A.T.; Liu, J.; Schultz, P.G.; Lesley, S.A.; Peters, E.C.; Siuzdak, G. Metabolomics analysis reveals large effects of gut microflora on mammalian blood metabolites. Proc. Natl. Acad. Sci. USA 2009, 106, 3698-3703. [CrossRef] [PubMed] 
144. Zheng, X.; Xie, G.; Zhao, A.; Zhao, L.; Yao, C.; Chiu, N.H.L.; Zhou, Z.; Bao, Y.; Jia, W.; Nicholson, J.K.; et al. The footprints of gut microbial-mammalian co-metabolism. J. Proteome Res. 2011, 10, 5512-5522. [CrossRef] [PubMed]

145. Gao, Z.; Yin, J.; Zhang, J.; Ward, R.E.; Martin, R.J.; Lefevre, M.; Cefalu, W.T.; Ye, J. Butyrate improves insulin sensitivity and increases energy expenditure in mice. Diabetes 2009, 58, 1509-1517. [CrossRef]

146. Rouse, M.; Singh, N.P.; Nagarkatti, P.S.; Nagarkatti, M. Indoles mitigate the development of experimental autoimmune encephalomyelitis by induction of reciprocal differentiation of regulatory T cells and Th17 cells. Br. J. Pharmacol. 2013, 169, 1305-1321. [CrossRef]

147. Koeth, R.A.; Wang, Z.; Levison, B.S.; Buffa, J.A.; Org, E.; Sheehy, B.T.; Britt, E.B.; Fu, X.; Wu, Y.; Li, L.; et al. Intestinal microbiota metabolism of 1-carnitine, a nutrient in red meat, promotes atherosclerosis. Nat. Med. 2013, 19, 576-585. [CrossRef]

148. Wegh, C.A.M.; Geerlings, S.Y.; Knol, J.; Roeselers, G.; Belzer, C. Postbiotics and Their Potential Applications in Early Life Nutrition and Beyond. Int. J. Mol. Sci. 2019, 20, 4673. [CrossRef]

149. Aguilar-Toalá, J.E.; Garcia-Varela, R.; Garcia, H.S.; Mata-Haro, V.; González-Córdova, A.F.; Vallejo-Cordoba, B.; Hernández-Mendoza, A. Postbiotics: An evolving term within the functional foods field. Trends Food Sci. Technol. 2018, 75, 105-114. [CrossRef]

150. Shenderov, B.A. Metabiotics: Novel idea or natural development of probiotic conception. Microb. Ecol. Heal. Dis. 2013, 24. [CrossRef]

151. Zhang, L.S.; Davies, S.S. Microbial metabolism of dietary components to bioactive metabolites: Opportunities for new therapeutic interventions. Genome Med. 2016, 8, 46. [CrossRef]

152. Kho, Z.Y.; Lal, S.K. The Human Gut Microbiome-A Potential Controller of Wellness and Disease. Front. Microbiol. 2018, 9, 1835. [CrossRef]

153. Zhang, Z.; Tang, H.; Chen, P.; Xie, H.; Tao, Y. Demystifying the manipulation of host immunity, metabolism, and extraintestinal tumors by the gut microbiome. Signal Transduct. Target. Ther. 2019, 4, 41. [CrossRef] [PubMed]

154. Donohoe, D.R.; Garge, N.; Zhang, X.; Sun, W.; O'Connell, T.M.; Bunger, M.K.; Bultman, S.J. The microbiome and butyrate regulate energy metabolism and autophagy in the mammalian colon. Cell Metab. 2011, 13, 517-526. [CrossRef] [PubMed]

155. Kaiko, G.E.; Ryu, S.H.; Koues, O.I.; Collins, P.L.; Solnica-Krezel, L.; Pearce, E.J.; Pearce, E.L.; Oltz, E.M.; Stappenbeck, T.S. The Colonic Crypt Protects Stem Cells from Microbiota-Derived Metabolites. Cell 2016, 165, 1708-1720. [CrossRef] [PubMed]

156. Round, J.L.; Mazmanian, S.K. Inducible Foxp3+ regulatory T-cell development by a commensal bacterium of the intestinal microbiota. Proc. Natl. Acad. Sci. USA 2010, 107, 12204-12209. [CrossRef]

157. Smith, P.M.; Howitt, M.R.; Panikov, N.; Michaud, M.; Gallini, C.A.; Bohlooly-Y, M.; Glickman, J.N.; Garrett, W.S. The microbial metabolites, short-chain fatty acids, regulate colonic T reg cell homeostasis. Science 2013, 341, 569-573. [CrossRef]

158. Atarashi, K.; Tanoue, T.; Shima, T.; Imaoka, A.; Kuwahara, T.; Momose, Y.; Cheng, G.; Yamasaki, S.; Saito, T.; Ohba, Y.; et al. Induction of colonic regulatory T cells by indigenous Clostridium species. Science 2011, 331, 337-341. [CrossRef]

159. Arpaia, N.; Green, J.A.; Moltedo, B.; Arvey, A.; Hemmers, S.; Yuan, S.; Treuting, P.M.; Rudensky, A.Y. A Distinct Function of Regulatory T Cells in Tissue Protection. Cell 2015, 162, 1078-1089. [CrossRef]

160. Singh, N.; Gurav, A.; Sivaprakasam, S.; Brady, E.; Padia, R.; Shi, H.; Thangaraju, M.; Prasad, P.D.; Manicassamy, S.; Munn, D.H.; et al. Activation of Gpr109a, receptor for niacin and the commensal metabolite butyrate, suppresses colonic inflammation and carcinogenesis. Immunity 2014, 40, 128-139. [CrossRef]

161. Fukuda, S.; Toh, H.; Hase, K.; Oshima, K.; Nakanishi, Y.; Yoshimura, K.; Tobe, T.; Clarke, J.M.; Topping, D.L.; Suzuki, T.; et al. Bifidobacteria can protect from enteropathogenic infection through production of acetate. Nature 2011, 469, 543-547. [CrossRef]

162. Gaudier, E.; Jarry, A.; Blottière, H.M.; de Coppet, P.; Buisine, M.P.; Aubert, J.P.; Laboisse, C.; Cherbut, C.; Hoebler, C. Butyrate specifically modulates MUC gene expression in intestinal epithelial goblet cells deprived of glucose. Am. J. Physiol. Liver Physiol. 2004, 287, G1168-G1174. [CrossRef] 
163. Macia, L.; Tan, J.; Vieira, A.T.; Leach, K.; Stanley, D.; Luong, S.; Maruya, M.; Ian McKenzie, C.; Hijikata, A.; Wong, C.; et al. Metabolite-sensing receptors GPR43 and GPR109A facilitate dietary fibre-induced gut homeostasis through regulation of the inflammasome. Nat. Commun. 2015, 6, 6734. [CrossRef]

164. Vinolo, M.A.R.; Rodrigues, H.G.; Hatanaka, E.; Sato, F.T.; Sampaio, S.C.; Curi, R. Suppressive effect of short-chain fatty acids on production of proinflammatory mediators by neutrophils. J. Nutr. Biochem. 2011, 22, 849-855. [CrossRef] [PubMed]

165. Usami, M.; Kishimoto, K.; Ohata, A.; Miyoshi, M.; Aoyama, M.; Fueda, Y.; Kotani, J. Butyrate and trichostatin A attenuate nuclear factor $\mathrm{\kappa B}$ activation and tumor necrosis factor $\alpha$ secretion and increase prostaglandin E2 secretion in human peripheral blood mononuclear cells. Nutr. Res. 2008, 28, 321-328. [CrossRef] [PubMed]

166. Chang, P.V.; Hao, L.; Offermanns, S.; Medzhitov, R. The microbial metabolite butyrate regulates intestinal macrophage function via histone deacetylase inhibition. Proc. Natl. Acad. Sci. USA 2014, 111, 2247-2252. [CrossRef]

167. Singh, N.; Thangaraju, M.; Prasad, P.D.; Martin, P.M.; Lambert, N.A.; Boettger, T.; Offermanns, S.; Ganapathy, V. Blockade of dendritic cell development by bacterial fermentation products butyrate and propionate through a transporter (Slc5a8)-dependent inhibition of histone deacetylases. J. Biol. Chem. 2010, 285, 27601-27608. [CrossRef] [PubMed]

168. Trompette, A.; Gollwitzer, E.S.; Yadava, K.; Sichelstiel, A.K.; Sprenger, N.; Ngom-Bru, C.; Blanchard, C.; Junt, T.; Nicod, L.P.; Harris, N.L.; et al. Gut microbiota metabolism of dietary fiber influences allergic airway disease and hematopoiesis. Nat. Med. 2014, 20, 159-166. [CrossRef] [PubMed]

169. Bakdash, G.; Vogelpoel, L.T.; van Capel, T.M.; Kapsenberg, M.L.; de Jong, E.C. Retinoic acid primes human dendritic cells to induce gut-homing, IL-10-producing regulatory T cells. Mucosal Immunol. 2015, 8, 265-278. [CrossRef]

170. Zhang, Z.; Li, J.; Zheng, W.; Zhao, G.; Zhang, H.; Wang, X.; Guo, Y.; Qin, C.; Shi, Y. Peripheral Lymphoid Volume Expansion and Maintenance Are Controlled by Gut Microbiota via RALDH+ Dendritic Cells. Immunity 2016, 44, 330-342. [CrossRef]

171. Mucida, D.; Park, Y.; Kim, G.; Turovskaya, O.; Scott, I.; Kronenberg, M.; Cheroutre, H. Reciprocal TH17 and Regulatory T Cell Differentiation Mediated by Retinoic Acid. Science 2007, 317, 256-260. [CrossRef]

172. Hall, J.A.; Cannons, J.L.; Grainger, J.R.; Dos Santos, L.M.; Hand, T.W.; Naik, S.; Wohlfert, E.A.; Chou, D.B.; Oldenhove, G.; Robinson, M.; et al. Essential role for retinoic acid in the promotion of CD4+ T cell effector responses via retinoic acid receptor alpha. Immunity 2011, 34, 435-447. [CrossRef]

173. Round, J.L.; Lee, S.M.; Li, J.; Tran, G.; Jabri, B.; Chatila, T.A.; Mazmanian, S.K. The Toll-Like Receptor 2 Pathway Establishes Colonization by a Commensal of the Human Microbiota. Science 2011, 332, 974-977. [CrossRef] [PubMed]

174. Mazmanian, S.K.; Round, J.L.; Kasper, D.L. A microbial symbiosis factor prevents intestinal inflammatory disease. Nature 2008, 453, 620-625. [CrossRef] [PubMed]

175. Ridaura, V.K.; Faith, J.J.; Rey, F.E.; Cheng, J.; Duncan, A.E.; Kau, A.L.; Griffin, N.W.; Lombard, V.; Henrissat, B.; Bain, J.R.; et al. Gut Microbiota from Twins Discordant for Obesity Modulate Metabolism in Mice. Science 2013, 341, 1241214. [CrossRef] [PubMed]

176. Pols, T.W.H.; Nomura, M.; Harach, T.; Lo Sasso, G.; Oosterveer, M.H.; Thomas, C.; Rizzo, G.; Gioiello, A.; Adorini, L.; Pellicciari, R.; et al. TGR5 Activation Inhibits Atherosclerosis by Reducing Macrophage Inflammation and Lipid Loading. Cell Metab. 2011, 14, 747-757. [CrossRef]

177. Devkota, S.; Wang, Y.; Musch, M.W.; Leone, V.; Fehlner-Peach, H.; Nadimpalli, A.; Antonopoulos, D.A.; Jabri, B.; Chang, E.B. Dietary-fat-induced taurocholic acid promotes pathobiont expansion and colitis in Il10-/- mice. Nature 2012, 487, 104-108. [CrossRef]

178. Levy, M.; Thaiss, C.A.; Zeevi, D.; Dohnalová, L.; Zilberman-Schapira, G.; Mahdi, J.A.; David, E.; Savidor, A.; Korem, T.; Herzig, Y.; et al. Microbiota-Modulated Metabolites Shape the Intestinal Microenvironment by Regulating NLRP6 Inflammasome Signaling. Cell 2015, 163, 1428-1443. [CrossRef] [PubMed]

179. Zelante, T.; Iannitti, R.G.; Cunha, C.; DeLuca, A.; Giovannini, G.; Pieraccini, G.; Zecchi, R.; D’Angelo, C.; Massi-Benedetti, C.; Fallarino, F.; et al. Tryptophan catabolites from microbiota engage aryl hydrocarbon receptor and balance mucosal reactivity via interleukin-22. Immunity 2013, 39, 372-385. [CrossRef]

180. Qiu, J.; Heller, J.J.; Guo, X.; Chen, Z.E.; Fish, K.; Fu, Y.-X.; Zhou, L. The Aryl Hydrocarbon Receptor Regulates Gut Immunity through Modulation of Innate Lymphoid Cells. Immunity 2012, 36, 92-104. [CrossRef] 
181. Roager, H.M.; Dragsted, L.O. Diet-derived microbial metabolites in health and disease. Nutr. Bull. 2019, 44, 216-227. [CrossRef]

182. Milligan, G.; Bolognini, D.; Sergeev, E. Ligands at the Free Fatty Acid Receptors 2/3 (GPR43/GPR41). Handb. Exp. Pharmacol. 2017, 236, 17-32.

183. Thaiss, C.A.; Zmora, N.; Levy, M.; Elinav, E. The microbiome and innate immunity. Nature 2016, 535, 65-74. [CrossRef] [PubMed]

184. Levin, A.D.; van den Brink, G.R. Selective inhibition of mucosal serotonin as treatment for IBD? Gut 2014, 63, 866-867. [CrossRef] [PubMed]

185. Fiorucci, S.; Biagioli, M.; Zampella, A.; Distrutti, E. Bile Acids Activated Receptors Regulate Innate Immunity. Front. Immunol. 2018, 9, 1853. [CrossRef]

186. Mertens, K.L.; Kalsbeek, A.; Soeters, M.R.; Eggink, H.M. Bile Acid Signaling Pathways from the Enterohepatic Circulation to the Central Nervous System. Front. Neurosci. 2017, 11. [CrossRef]

187. Linsalata, M.; Giannini, R.; Notarnicola, M.; Cavallini, A. Peroxisome proliferator-activated receptor gamma and spermidine/spermine N1-acetyltransferase gene expressions are significantly correlated in human colorectal cancer. BMC Cancer 2006, 6, 191. [CrossRef]

188. Ahern, G.P.; Wang, X.; Miyares, R.L. Polyamines are potent ligands for the capsaicin receptor TRPV1. J. Biol. Chem. 2006, 281, 8991-8995. [CrossRef] [PubMed]

189. Zhang, M.; Wang, H.; Tracey, K.J. Regulation of macrophage activation and inflammation by spermine: A new chapter in an old story. Crit. Care Med. 2000, 28, N60-N66. [CrossRef] [PubMed]

190. Fennema, D.; Phillips, I.R.; Shephard, E.A. Trimethylamine and Trimethylamine N-Oxide, a Flavin-Containing Monooxygenase 3 (FMO3)-Mediated Host-Microbiome Metabolic Axis Implicated in Health and Disease. Drug Metab. Dispos. 2016, 44, 1839-1850. [CrossRef] [PubMed]

191. Seldin, M.M.; Meng, Y.; Qi, H.; Zhu, W.; Wang, Z.; Hazen, S.L.; Lusis, A.J.; Shih, D.M. Trimethylamine N-Oxide Promotes Vascular Inflammation Through Signaling of Mitogen-Activated Protein Kinase and Nuclear Factor-kB. J. Am. Heart Assoc. 2016, 5. [CrossRef] [PubMed]

192. Bae, E.-A.; Choo, M.-K.; Park, E.-K.; Park, S.-Y.; Shin, H.-Y.; Kim, D.-H. Metabolism of Ginsenoside Rc by Human Intestinal Bacteria and Its Related Antiallergic Activity. Biol. Pharm. Bull. 2002, 25, 743-747. [CrossRef] [PubMed]

193. Stark, A.H.; Madar, Z. In vitro production of short-chain fatty acids by bacterial fermentation of dietary fiber compared with effects of those fibers on hepatic sterol synthesis in rats. J. Nutr. 1993, 123, 2166-2173. [PubMed]

194. Macfarlane, S.; Macfarlane, G.T. Regulation of short-chain fatty acid production. Proc. Nutr. Soc. 2003, 62, 67-72. [CrossRef] [PubMed]

195. Gérard, P. Metabolism of cholesterol and bile acids by the gut microbiota. Pathogens 2013, 3, 14-24. [CrossRef]

196. Surprenant, A.; Rassendren, F.; Kawashima, E.; North, R.A.; Buell, G. The cytolytic P2Z receptor for extracellular ATP identified as a P2X receptor (P2X7). Science 1996, 272, 735-738. [CrossRef]

197. Wang, H.; Chen, J.; Hollister, K.; Sowers, L.C.; Forman, B.M. Endogenous bile acids are ligands for the nuclear receptor FXR/BAR. Mol. Cell 1999, 3, 543-553. [CrossRef]

198. Maruyama, T.; Miyamoto, Y.; Nakamura, T.; Tamai, Y.; Okada, H.; Sugiyama, E.; Nakamura, T.; Itadani, H.; Tanaka, K. Identification of membrane-type receptor for bile acids (M-BAR). Biochem. Biophys. Res. Commun. 2002, 298, 714-719. [CrossRef]

199. Roberts, E.; Golas, C.; Okey, A. Ah Receptor Mediating Induction of Aryl Hydrocarbon Hydroxylase: Detection in Human Lung by Binding of 2,3,7,8-[3H]Tetrachlorodibenzo-p-dioxin. Cancer Res. 1986, 46, 3739-3743.

200. Kliewer, S.A.; Moore, J.T.; Wade, L.; Staudinger, J.L.; Watson, M.A.; Jones, S.A.; McKee, D.D.; Oliver, B.B.; Willson, T.M.; Zetterström, R.H.; et al. An orphan nuclear receptor activated by pregnanes defines a novel steroid signaling pathway. Cell 1998, 92, 73-82. [CrossRef]

201. Venkatesh, M.; Mukherjee, S.; Wang, H.; Li, H.; Sun, K.; Benechet, A.P.; Qiu, Z.; Maher, L.; Redinbo, M.R.; Phillips, R.S.; et al. Symbiotic bacterial metabolites regulate gastrointestinal barrier function via the xenobiotic sensor PXR and toll-like receptor 4. Immunity 2014, 41, 296-310. [CrossRef]

202. Holmes, E.; Loo, R.L.; Stamler, J.; Bictash, M.; Yap, I.K.S.; Chan, Q.; Ebbels, T.; De Iorio, M.; Brown, I.J.; Veselkov, K.A.; et al. Human metabolic phenotype diversity and its association with diet and blood pressure. Nature 2008, 453, 396-400. [CrossRef] 
203. Smith, M.I.; Yatsunenko, T.; Manary, M.J.; Trehan, I.; Mkakosya, R.; Cheng, J.; Kau, A.L.; Rich, S.S.; Concannon, P.; Mychaleckyj, J.C.; et al. Gut microbiomes of Malawian twin pairs discordant for kwashiorkor. Science 2013, 339, 548-554. [CrossRef] [PubMed]

204. Brown, A.J.; Goldsworthy, S.M.; Barnes, A.A.; Eilert, M.M.; Tcheang, L.; Daniels, D.; Muir, A.I.; Wigglesworth, M.J.; Kinghorn, I.; Fraser, N.J.; et al. The orphan G protein-coupled receptors GPR41 and GPR43 are activated by propionate and other short chain carboxylic acids. J. Biol. Chem. 2003, 278, 11312-11319. [CrossRef] [PubMed]

205. Le Poul, E.; Loison, C.; Struyf, S.; Springael, J.Y.; Lannoy, V.; Decobecq, M.E.; Brezillon, S.; Dupriez, V.; Vassart, G.; Van Damme, J.; et al. Functional characterization of human receptors for short chain fatty acids and their role in polymorphonuclear cell activation. J. Biol. Chem. 2003, 278, 25481-25489. [CrossRef] [PubMed]

206. Seljeset, S.; Siehler, S. Receptor-specific regulation of ERK1/2 activation by members of the "free fatty acid receptor" family. J. Recept. Signal Transduct. 2012, 32, 196-201. [CrossRef]

207. Miyauchi, S.; Gopal, E.; Fei, Y.J.; Ganapathy, V. Functional Identification of SLC5A8, a Tumor Suppressor Down-regulated in Colon Cancer, as a Na+-coupled Transporter for Short-chain Fatty Acids. J. Biol. Chem. 2004, 279, 13293-13296. [CrossRef]

208. Thangaraju, M.; Cresci, G.A.; Liu, K.; Ananth, S.; Gnanaprakasam, J.P.; Browning, D.D.; Mellinger, J.D.; Smith, S.B.; Digby, G.J.; Lambert, N.A.; et al. GPFM 09A is a G-protein-coupled receptor for the bacterial fermentation product butyrate and functions as a tumor suppressor in colon. Cancer Res. 2009, 69, 2826-2832. [CrossRef]

209. Steliou, K.; Boosalis, M.S.; Perrine, S.P.; Sangerman, J.; Faller, D.V. Butyrate histone deacetylase inhibitors. Biores. Open Access 2012, 1, 192-198. [CrossRef]

210. Donohoe, D.R.; Collins, L.B.; Wali, A.; Bigler, R.; Sun, W.; Bultman, S.J. The Warburg Effect Dictates the Mechanism of Butyrate-Mediated Histone Acetylation and Cell Proliferation. Mol. Cell 2012, 48, 612-626. [CrossRef]

211. Koh, A.; De Vadder, F.; Kovatcheva-Datchary, P.; Bäckhed, F. From Dietary Fiber to Host Physiology: Short-Chain Fatty Acids as Key Bacterial Metabolites. Cell 2016, 165, 1332-1345. [CrossRef]

212. Alex, S.; Lange, K.; Amolo, T.; Grinstead, J.S.; Haakonsson, A.K.; Szalowska, E.; Koppen, A.; Mudde, K.; Haenen, D.; Al-Lahham, S.; et al. Short-Chain Fatty Acids Stimulate Angiopoietin-Like 4 Synthesis in Human Colon Adenocarcinoma Cells by Activating Peroxisome Proliferator-Activated Receptor. Mol. Cell. Biol. 2013, 33, 1303-1316. [CrossRef]

213. Elamin, E.E.; Masclee, A.A.; Dekker, J.; Pieters, H.-J.; Jonkers, D.M. Short-Chain Fatty Acids Activate AMP-Activated Protein Kinase and Ameliorate Ethanol-Induced Intestinal Barrier Dysfunction in Caco-2 Cell Monolayers. J. Nutr. 2013, 143, 1872-1881. [CrossRef] [PubMed]

214. Willemsen, L.E.M.; Koetsier, M.A.; Van Deventer, S.J.H.; Van Tol, E.A.F. Short chain fatty acids stimulate epithelial mucin 2 expression through differential effects on prostaglandin E1 and E2 production by intestinal myofibroblasts. Gut 2003, 52, 1442-1447. [CrossRef] [PubMed]

215. Assa, A.; Vong, L.; Pinnell, L.J.; Avitzur, N.; Johnson-Henry, K.C.; Sherman, P.M. Vitamin D deficiency promotes epithelial barrier dysfunction and intestinal inflammation. J. Infect. Dis. 2014, 210, 1296-1305. [CrossRef] [PubMed]

216. Guttman, J.A.; Li, Y.; Wickham, M.E.; Deng, W.; Vogl, A.W.; Finlay, B.B. Attaching and effacing pathogen-induced tight junction disruption in vivo. Cell. Microbiol. 2006, 8, 634-645. [CrossRef]

217. Scheppach, W.; Bartram, H.P.; Richter, F.; Müller, J.G.; Greinwald, K.; Tauschel, H.D.; Gierend, M.; Weber, A.; Hegemann, D.; Kubetzko, W.; et al. Treatment of distal ulcerative colitis with short-chain fatty acid enemas. A placebo-controlled trial. Dig. Dis. Sci. 1996, 41, 2254-2259. [CrossRef]

218. Butzner, J.D.; Parmar, R.; Bell, C.J.; Dalal, V. Butyrate enema therapy stimulates mucosal repair in experimental colitis in the rat. Gut 1996, 38, 568-573. [CrossRef]

219. Martinez-Guryn, K.; Hubert, N.; Frazier, K.; Urlass, S.; Musch, M.W.; Ojeda, P.; Pierre, J.F.; Miyoshi, J.; Sontag, T.J.; Cham, C.M.; et al. Small Intestine Microbiota Regulate Host Digestive and Absorptive Adaptive Responses to Dietary Lipids. Cell Host Microbe 2018, 23, 458-469.e5. [CrossRef]

220. Maciejewska, D.; Skonieczna-Zydecka, K.; Lukomska, A.; Gutowska, I.; Dec, K.; Kupnicka, P.; Palma, J.; Pilutin, A.; Marlicz, W.; Stachowska, E. The short chain fatty acids and lipopolysaccharides status in Sprague-Dawley rats fed with high-fat and high-cholesterol diet. J. Physiol. Pharmacol. 2018, 69. 
221. Parada Venegas, D.; De la Fuente, M.K.; Landskron, G.; González, M.J.; Quera, R.; Dijkstra, G.; Harmsen, H.J.M.; Faber, K.N.; Hermoso, M.A. Short Chain Fatty Acids (SCFAs)-Mediated Gut Epithelial and Immune Regulation and Its Relevance for Inflammatory Bowel Diseases. Front. Immunol. 2019, 10, 277. [CrossRef] [PubMed]

222. Cox, M.A.; Jackson, J.; Stanton, M.; Rojas-Triana, A.; Bober, L.; Laverty, M.; Yang, X.; Zhu, F.; Liu, J.; Wang, S.; et al. Short-chain fatty acids act as antiinflammatory mediators by regulating prostaglandin $\mathrm{E} 2$ and cytokines. World J. Gastroenterol. 2009, 15, 5549-5557. [CrossRef]

223. Thaiss, C.A.; Itav, S.; Rothschild, D.; Meijer, M.T.; Levy, M.; Moresi, C.; Dohnalová, L.; Braverman, S.; Rozin, S.; Malitsky, S.; et al. Persistent microbiome alterations modulate the rate of post-dieting weight regain. Nature 2016, 540, 544-551. [CrossRef]

224. Fraga, C.G.; Oteiza, P.I. Dietary flavonoids: Role of (-)-epicatechin and related procyanidins in cell signaling. Free Radic. Biol. Med. 2011, 51, 813-823. [CrossRef] [PubMed]

225. Rivera, L.; Morón, R.; Sánchez, M.; Zarzuelo, A.; Galisteo, M. Quercetin ameliorates metabolic syndrome and improves the inflammatory status in obese Zucker rats. Obesity 2008, 16, 2081-2087. [CrossRef] [PubMed]

226. Son, M.; Ko, J.I.; Kim, W.B.; Kang, H.K.; Kim, B.K. Taurine Can Ameliorate Inflammatory Bowel Disease in Rats. In Advances in Experimental Medicine and Biology; Springer: Boston, MA, USA, 1998; Volume 442, pp. 291-298.

227. Chery, J.; Dvoskin, D.; Morato, F.P.; Fahoum, B. Lactobacillus fermentum, a pathogen in documented cholecystitis. Int. J. Surg. Case Rep. 2013, 4, 662-664. [CrossRef]

228. Zagato, E.; Mileti, E.; Massimiliano, L.; Fasano, F.; Budelli, A.; Penna, G.; Rescigno, M. Lactobacillus paracasei CBA 174 metabolic products and fermented milk for infant formula have anti-inflammatory activity on dendritic cells in Vitro and protective effects against colitis and an enteric pathogen in Vivo. PLoS ONE 2014, 9, e87615. [CrossRef]

229. Jones, S.E.; Versalovic, J. Probiotic Lactobacillus reuteri biofilms produce antimicrobial and anti-inflammatory factors. BMC Microbiol. 2009, 9, 35. [CrossRef]

230. Bermudez-Brito, M.; Muñoz-Quezada, S.; Gomez-Llorente, C.; Matencio, E.; Bernal, M.J.; Romero, F.; Gil, A. Human Intestinal Dendritic Cells Decrease Cytokine Release against Salmonella Infection in the Presence of Lactobacillus paracasei upon TLR Activation. PLoS ONE 2012, 7, e43197. [CrossRef]

231. Ma, G.; Pan, B.; Chen, Y.; Guo, C.; Zhao, M.; Zheng, L.; Chen, B. Trimethylamine N-oxide in atherogenesis: Impairing endothelial self-repair capacity and enhancing monocyte adhesion. Biosci. Rep. 2017, 37. [CrossRef]

232. Preciado, G.M.; Michel, M.M.; Villarreal-Morales, S.L.; Flores-Gallegos, A.C.; Aguirre-Joya, J.; Morlett-Chávez, J.; Aguilar, C.N.; Rodríguez-Herrera, R. Bacteriocins and Its Use for Multidrug-Resistant Bacteria Control. In Antibiotic Resistance; Elsevier: Amsterdam, The Netherlands, 2016; pp. 329-349. ISBN 9780128036686.

233. Lages, M.C.A.; Beilharz, K.; Morales Angeles, D.; Veening, J.W.; Scheffers, D.J. The localization of key Bacillus subtilis penicillin binding proteins during cell growth is determined by substrate availability. Environ. Microbiol. 2013, 15, 3272-3281. [CrossRef]

234. Vilchèze, C.; Hartman, T.; Weinrick, B.; Jacobs, W.R. Mycobacterium tuberculosis is extraordinarily sensitive to killing by a vitamin C-induced Fenton reaction. Nat. Commun. 2013, 4, 1881. [CrossRef]

235. Tukenmez, U.; Aktas, B.; Aslim, B.; Yavuz, S. The relationship between the structural characteristics of lactobacilli-EPS and its ability to induce apoptosis in colon cancer cells in vitro. Sci. Rep. 2019, 9, 8268. [CrossRef]

236. Paulos, C.M.; Wrzesinski, C.; Kaiser, A.; Hinrichs, C.S.; Chieppa, M.; Cassard, L.; Palmer, D.C.; Boni, A.; Muranski, P.; Yu, Z.; et al. Microbial translocation augments the function of adoptively transferred self/tumor-specific CD8+ T cells via TLR4 signaling. J. Clin. Investig. 2007, 117, 2197-2204. [CrossRef] [PubMed]

237. Abotaleb, M.; Samuel, S.; Varghese, E.; Varghese, S.; Kubatka, P.; Liskova, A.; Büsselberg, D. Flavonoids in Cancer and Apoptosis. Cancers (Basel) 2018, 11, 28. [CrossRef]

238. Tin, A.S.; Park, A.H.; Sundar, S.N.; Firestone, G.L. Essential role of the cancer stem/progenitor cell marker nucleostemin for indole-3-carbinol anti-proliferative responsiveness in human breast cancer cells. BMC Biol. 2014, 12, 72. [CrossRef] [PubMed] 
239. Chinni, S.R.; Li, Y.; Upadhyay, S.; Koppolu, P.K.; Sarkar, F.H. Indole-3-carbinol (I3C) induced cell growth inhibition, G1 cell cycle arrest and apoptosis in prostate cancer cells. Oncogene 2001, 20, 2927-2936. [CrossRef] [PubMed]

240. Hashimoto, T.; Perlot, T.; Rehman, A.; Trichereau, J.; Ishiguro, H.; Paolino, M.; Sigl, V.; Hanada, T.; Hanada, R.; Lipinski, S.; et al. ACE2 links amino acid malnutrition to microbial ecology and intestinal inflammation. Nature 2012, 487, 477-481. [CrossRef]

241. Taleb, S. Tryptophan Dietary Impacts Gut Barrier and Metabolic Diseases. Front. Immunol. 2019, 10. [CrossRef]

242. Clarke, G.; Grenham, S.; Scully, P.; Fitzgerald, P.; Moloney, R.D.; Shanahan, F.; Dinan, T.G.; Cryan, J.F. The microbiome-gut-brain axis during early life regulates the hippocampal serotonergic system in a sex-dependent manner. Mol. Psychiatry 2013, 18, 666-673. [CrossRef]

243. Yano, J.M.; Yu, K.; Donaldson, G.P.; Shastri, G.G.; Ann, P.; Ma, L.; Nagler, C.R.; Ismagilov, R.F.; Mazmanian, S.K.; Hsiao, E.Y. Indigenous bacteria from the gut microbiota regulate host serotonin biosynthesis. Cell 2015, 161, 264-276. [CrossRef]

244. Smith, E.A.; Macfarlane, G.T. Enumeration of human colonie bacteria producing phenolic and indolic compounds: Effects of $\mathrm{pH}$, carbohydrate availability and retention time on dissimilatory aromatic amino acid metabolism. J. Appl. Bacteriol. 1996, 81, 288-302. [CrossRef]

245. Lee, J.-H.; Lee, J. Indole as an intercellular signal in microbial communities. FEMS Microbiol. Rev. 2010, 34, 426-444. [CrossRef] [PubMed]

246. Elsden, S.R.; Hilton, M.G.; Waller, J.M. The end products of the metabolism of aromatic amino acids by clostridia. Arch. Microbiol. 1976, 107, 283-288. [CrossRef] [PubMed]

247. Devlin, A.S.; Marcobal, A.; Dodd, D.; Nayfach, S.; Plummer, N.; Meyer, T.; Pollard, K.S.; Sonnenburg, J.L.; Fischbach, M.A. Modulation of a Circulating Uremic Solute via Rational Genetic Manipulation of the Gut Microbiota. Cell Host Microbe 2016, 20, 709-715. [CrossRef] [PubMed]

248. Williams, B.B.; Van Benschoten, A.H.; Cimermancic, P.; Donia, M.S.; Zimmermann, M.; Taketani, M.; Ishihara, A.; Kashyap, P.C.; Fraser, J.S.; Fischbach, M.A. Discovery and characterization of gut microbiota decarboxylases that can produce the neurotransmitter tryptamine. Cell Host Microbe 2014, 16, 495-503. [CrossRef] [PubMed]

249. Dodd, D.; Spitzer, M.H.; Van Treuren, W.; Merrill, B.D.; Hryckowian, A.J.; Higginbottom, S.K.; Le, A.; Cowan, T.M.; Nolan, G.P.; Fischbach, M.A.; et al. A gut bacterial pathway metabolizes aromatic amino acids into nine circulating metabolites. Nature 2017, 551, 648-652. [CrossRef]

250. Wilck, N.; Matus, M.G.; Kearney, S.M.; Olesen, S.W.; Forslund, K.; Bartolomaeus, H.; Haase, S.; Mahler, A.; Balogh, A.; Marko, L.; et al. Salt-responsive gut commensal modulates TH17 axis and disease. Nature 2017, 551, 585-589. [CrossRef]

251. Russell, W.R.; Duncan, S.H.; Scobbie, L.; Duncan, G.; Cantlay, L.; Calder, A.G.; Anderson, S.E.; Flint, H.J. Major phenylpropanoid-derived metabolites in the human gut can arise from microbial fermentation of protein. Mol. Nutr. Food Res. 2013, 57, 523-535. [CrossRef]

252. Aragozzini, F.; Ferrari, A.; Pacini, N.; Gualandris, R. Indole-3-lactic acid as a tryptophan metabolite produced by Bifidobacterium spp. Appl. Environ. Microbiol. 1979, 38, 544-546. [CrossRef]

253. Sonowal, R.; Swimm, A.; Sahoo, A.; Luo, L.; Matsunaga, Y.; Wu, Z.; Bhingarde, J.A.; Ejzak, E.A.; Ranawade, A.; Qadota, H.; et al. Indoles from commensal bacteria extend healthspan. Proc. Natl. Acad. Sci. USA 2017, 114, E7506-E7515. [CrossRef]

254. Lee, J.-H.; Wood, T.K.; Lee, J. Roles of Indole as an Interspecies and Interkingdom Signaling Molecule. Trends Microbiol. 2015, 23, 707-718. [CrossRef]

255. Lee, J.; Jayaraman, A.; Wood, T.K. Indole is an inter-species biofilm signal mediated by SdiA. BMC Microbiol. 2007, 7, 42. [CrossRef] [PubMed]

256. Lee, J.; Attila, C.; Cirillo, S.L.G.; Cirillo, J.D.; Wood, T.K. Indole and 7-hydroxyindole diminish Pseudomonas aeruginosa virulence. Microb. Biotechnol. 2009, 2, 75-90. [CrossRef] [PubMed]

257. Chu, W.; Zere, T.R.; Weber, M.M.; Wood, T.K.; Whiteley, M.; Hidalgo-Romano, B.; Valenzuela, E.; McLean, R.J.C. Indole production promotes escherichia coli mixed-culture growth with Pseudomonas aeruginosa by inhibiting quorum signaling. Appl. Environ. Microbiol. 2012, 78, 411-419. [CrossRef]

258. Nikaido, E.; Giraud, E.; Baucheron, S.; Yamasaki, S.; Wiedemann, A.; Okamoto, K.; Takagi, T.; Yamaguchi, A.; Cloeckaert, A.; Nishino, K. Effects of indole on drug resistance and virulence of Salmonella enterica serovar Typhimurium revealed by genome-wide analyses. Gut Pathog. 2012, 4, 5. [CrossRef] 
259. Vega, N.M.; Allison, K.R.; Khalil, A.S.; Collins, J.J. Signaling-mediated bacterial persister formation. Nat. Chem. Biol. 2012, 8, 431-433. [CrossRef] [PubMed]

260. Hirakawa, H.; Hayashi-Nishino, M.; Yamaguchi, A.; Nishino, K. Indole enhances acid resistance in Escherichia coli. Microb. Pathog. 2010, 49, 90-94. [CrossRef] [PubMed]

261. Vega, N.M.; Allison, K.R.; Samuels, A.N.; Klempner, M.S.; Collins, J.J. Salmonella typhimurium intercepts Escherichia coli signaling to enhance antibiotic tolerance. Proc. Natl. Acad. Sci. USA 2013, 110, 14420-14425. [CrossRef] [PubMed]

262. Molina-Santiago, C.; Daddaoua, A.; Fillet, S.; Duque, E.; Ramos, J.L. Interspecies signalling: Pseudomonas putida efflux pump TtgGHI is activated by indole to increase antibiotic resistance. Environ. Microbiol. 2014, 16, 1267-1281. [CrossRef]

263. Chimerel, C.; Field, C.M.; Piñero-Fernandez, S.; Keyser, U.F.; Summers, D.K. Indole prevents Escherichia coli cell division by modulating membrane potential. Biochim. Biophys. Acta-Biomembr. 2012, 1818, 1590-1594. [CrossRef]

264. Kim, J.; Hong, H.; Heo, A.; Park, W. Indole toxicity involves the inhibition of adenosine triphosphate production and protein folding in Pseudomonas putida. FEMS Microbiol. Lett. 2013, 343, 89-99. [CrossRef]

265. Lee, J.H.; Cho, H.S.; Kim, Y.; Kim, J.A.; Banskota, S.; Cho, M.H.; Lee, J. Indole and 7-benzyloxyindole attenuate the virulence of Staphylococcus aureus. Appl. Microbiol. Biotechnol. 2013, 97, 4543-4552. [CrossRef] [PubMed]

266. Plovier, H.; Cani, P.D. Enteroendocrine Cells: Metabolic Relays between Microbes and Their Host. In Endocrine Development; Karger Publishers: Basel, Switzerland, 2017; Volume 32, pp. 139-164.

267. Levy, M.; Blacher, E.; Elinav, E. Microbiome, metabolites and host immunity. Curr. Opin. Microbiol. 2017, 35, 8-15. [CrossRef] [PubMed]

268. Hubbard, T.D.; Murray, I.A.; Perdew, G.H. Special section on drug metabolism and the microbiome-Minireview indole and tryptophan metabolism: Endogenous and dietary routes to ah receptor activation. Drug Metab. Dispos. 2015, 43, 1522-1535. [CrossRef]

269. Zhao, H.; Chen, L.; Yang, T.; Feng, Y.-L.; Vaziri, N.D.; Liu, B.-L.; Liu, Q.-Q.; Guo, Y.; Zhao, Y.-Y. Aryl hydrocarbon receptor activation mediates kidney disease and renal cell carcinoma. J. Transl. Med. 2019, 17, 302. [CrossRef] [PubMed]

270. Stockinger, B.; Di Meglio, P.; Gialitakis, M.; Duarte, J.H. The Aryl Hydrocarbon Receptor: Multitasking in the Immune System. Annu. Rev. Immunol. 2014, 32, 403-432. [CrossRef]

271. Gutiérrez-Vázquez, C.; Quintana, F.J. Regulation of the Immune Response by the Aryl Hydrocarbon Receptor. Immunity 2018. [CrossRef] [PubMed]

272. Stejskalova, L.; Dvorak, Z.; Pavek, P. Endogenous and Exogenous Ligands of Aryl Hydrocarbon Receptor: Current State of Art. Curr. Drug Metab. 2011, 12, 198-212. [CrossRef]

273. Su, H.-H.; Lin, H.-T.; Suen, J.-L.; Sheu, C.C.; Yokoyama, K.K.; Huang, S.-K.; Cheng, C.M. Aryl hydrocarbon receptor-ligand axis mediates pulmonary fibroblast migration and differentiation through increased arachidonic acid metabolism. Toxicology 2016, 370, 116-126. [CrossRef]

274. Chiaro, C.R.; Patel, R.D.; Perdew, G.H. 12(R)-hydroxy-5(Z),8(Z),10(E),14(Z)-eicosatetraenoic acid [12(R)-HETE], an arachidonic acid derivative, is an activator of the aryl hydrocarbon receptor. Mol. Pharmacol. 2008, 74, 1649-1656. [CrossRef]

275. Quintana, F.J.; Sherr, D.H. Aryl hydrocarbon receptor control of adaptive immunity. Pharmacol. Rev. 2013, 65, 1148-1161. [CrossRef]

276. Kerkvliet, N.I.; Shepherd, D.M.; Baecher-Steppan, L. T lymphocytes are direct, aryl hydrocarbon receptor (AhR)-dependent targets of 2,3,7,8-tetrachlorodibenzo-p-dioxin (TCDD): AhR expression in both CD4+ and CD8+ $\mathrm{T}$ cells is necessary for full suppression of a cytotoxic $\mathrm{T}$ lymphocyte response by TCDD. Toxicol. Appl. Pharmacol. 2002, 185, 146-152. [CrossRef] [PubMed]

277. Singh, N.P.; Singh, U.P.; Rouse, M.; Zhang, J.; Chatterjee, S.; Nagarkatti, P.S.; Nagarkatti, M. Dietary Indoles Suppress Delayed-Type Hypersensitivity by Inducing a Switch from Proinflammatory Th17 Cells to Anti-Inflammatory Regulatory T Cells through Regulation of MicroRNA. J. Immunol. 2016, 196, 1108-1122. [CrossRef] [PubMed]

278. Mezrich, J.D.; Fechner, J.H.; Zhang, X.; Johnson, B.P.; Burlingham, W.J.; Bradfield, C.A. An Interaction between Kynurenine and the Aryl Hydrocarbon Receptor Can Generate Regulatory T Cells. J. Immunol. 2010, 185, 3190-3198. [CrossRef] [PubMed] 
279. Veldhoen, M.; Hirota, K.; Westendorf, A.M.; Buer, J.; Dumoutier, L.; Renauld, J.C.; Stockinger, B. The aryl hydrocarbon receptor links TH17-cell-mediated autoimmunity to environmental toxins. Nature 2008, 453, 106-109. [CrossRef]

280. Kimura, A.; Naka, T.; Nohara, K.; Fujii-Kuriyama, Y.; Kishimoto, T. Aryl hydrocarbon receptor regulates Stat1 activation and participates in the development of Th17 cells. Proc. Natl. Acad. Sci. USA 2008, 105, 9721-9726. [CrossRef]

281. Cui, G.; Qin, X.; Wu, L.; Zhang, Y.; Sheng, X.; Yu, Q.; Sheng, H.; Xi, B.; Zhang, J.Z.; Zang, Y.Q. Liver X receptor (LXR) mediates negative regulation of mouse and human Th17 differentiation. J. Clin. Investig. 2011, 121, 658-670. [CrossRef]

282. Quintana, F.J.; Basso, A.S.; Iglesias, A.H.; Korn, T.; Farez, M.F.; Bettelli, E.; Caccamo, M.; Oukka, M.; Weiner, H.L. Control of Treg and Th17 cell differentiation by the aryl hydrocarbon receptor. Nature 2008, 453, 65-71. [CrossRef]

283. Zhang, L.; Ma, J.; Takeuchi, M.; Usui, Y.; Hattori, T.; Okunuki, Y.; Yamakawa, N.; Kezuka, T.; Kuroda, M.; Goto, H. Suppression of experimental autoimmune uveoretinitis by inducing differentiation of regulatory T cells via activation of aryl hydrocarbon receptor. Investig. Ophthalmol. Vis. Sci. 2010, 51, 2109-2117. [CrossRef]

284. Benson, J.M.; Shepherd, D.M. Aryl hydrocarbon receptor activation by TCDD reduces inflammation associated with Crohn's disease. Toxicol. Sci. 2011, 120, 68-78. [CrossRef]

285. Singh, N.P.; Singh, U.P.; Singh, B.; Price, R.L.; Nagarkatti, M.; Nagarkatti, P.S. Activation of Aryl hydrocarbon receptor (AhR) leads to reciprocal epigenetic regulation of Foxp3 and IL-17 expression and amelioration of experimental colitis. PLoS ONE 2011, 6, e23522. [CrossRef]

286. Kerkvliet, N.I.; Steppan, L.B.; Vorachek, W.; Oda, S.; Farrer, D.; Wong, C.P.; Pham, D.; Mourich, D.V. Activation of aryl hydrocarbon receptor by TCDD prevents diabetes in NOD mice and increases Foxp3 + T cells in pancreatic lymph nodes. Immunotherapy 2009, 1, 539-547. [PubMed]

287. Lanis, J.M.; Alexeev, E.E.; Curtis, V.F.; Kitzenberg, D.A.; Kao, D.J.; Battista, K.D.; Gerich, M.E.; Glover, L.E.; Kominsky, D.J.; Colgan, S.P. Tryptophan metabolite activation of the aryl hydrocarbon receptor regulates IL-10 receptor expression on intestinal epithelia. Mucosal Immunol. 2017, 10, 1133-1144. [CrossRef] [PubMed]

288. Lamas, B.; Richard, M.L.; Leducq, V.; Pham, H.P.; Michel, M.L.; Da Costa, G.; Bridonneau, C.; Jegou, S.; Hoffmann, T.W.; Natividad, J.M.; et al. CARD9 impacts colitis by altering gut microbiota metabolism of tryptophan into aryl hydrocarbon receptor ligands. Nat. Med. 2016, 22, 598-605. [CrossRef]

289. Monteleone, I.; Rizzo, A.; Sarra, M.; Sica, G.; Sileri, P.; Biancone, L.; MacDonald, T.T.; Pallone, F.; Monteleone, G. Aryl Hydrocarbon Receptor-Induced Signals Up-regulate IL-22 Production and Inhibit Inflammation in the Gastrointestinal Tract. Gastroenterology 2011, 141, 237-248.e1. [CrossRef]

290. Lin, L.; Tan, B.; Pantapalangkoor, P.; Ho, T.; Baquir, B.; Tomaras, A.; Montgomery, J.I.; Reilly, U.; Barbacci, E.G.; Hujer, K.; et al. Inhibition of LpxC Protects Mice from Resistant Acinetobacter baumannii by Modulating Inflammation and Enhancing Phagocytosis. MBio 2012, 3. [CrossRef]

291. Hauser, A.R.; Mecsas, J.; Moir, D.T. Beyond antibiotics: New therapeutic approaches for bacterial infections. Clin. Infect. Dis. 2016, 63, 89-95. [CrossRef]

292. Jiang, Q.; Chen, J.; Yang, C.; Yin, Y.; Yao, K. Quorum Sensing: A Prospective Therapeutic Target for Bacterial Diseases. Biomed Res. Int. 2019, 2019, 1-15. [CrossRef] [PubMed]

293. Metidji, A.; Omenetti, S.; Crotta, S.; Li, Y.; Nye, E.; Ross, E.; Li, V.; Maradana, M.R.; Schiering, C.; Stockinger, B. The Environmental Sensor AHR Protects from Inflammatory Damage by Maintaining Intestinal Stem Cell Homeostasis and Barrier Integrity. Immunity 2018, 49, 353-362.e5. [CrossRef]

294. Natividad, J.M.; Agus, A.; Planchais, J.; Lamas, B.; Jarry, A.C.; Martin, R.; Michel, M.L.; Chong-Nguyen, C.; Roussel, R.; Straube, M.; et al. Impaired Aryl Hydrocarbon Receptor Ligand Production by the Gut Microbiota Is a Key Factor in Metabolic Syndrome. Cell Metab. 2018, 28, 737-749.e4. [CrossRef]

295. Lanktree, M.B.; Hegele, R.A. Metabolic Syndrome. In Genomic and Precision Medicine; Elsevier: Amsterdam, The Netherlands, 2017; pp. 283-299. ISBN 9780128006542.

296. Romani, L.; Puccetti, P.; Zelante, T.; Ricci, M.; Giovagnoli, S. Indole-3-aldehyde for Treating Immune Dysreactive Diseases. European Patent EP3035967B1, 18 December 2019.

297. Puccetti, M.; Giovagnoli, S.; Zelante, T.; Romani, L.; Ricci, M. Development of Novel Indole-3-Aldehyde-Loaded Gastro-Resistant Spray-Dried Microparticles for Postbiotic Small Intestine Local Delivery. J. Pharm. Sci. 2018, 107, 2341-2353. [CrossRef] 
298. Guo, X.; Qiu, J.; Tu, T.; Yang, X.; Deng, L.; Anders, R.A.; Zhou, L.; Fu, Y.X. Induction of innate lymphoid cell-derived interleukin-22 by the transcription factor STAT3 mediates protection against intestinal infection. Immunity 2014, 40, 25-39. [CrossRef] [PubMed]

299. Swimm, A.; Giver, C.R.; DeFilipp, Z.; Rangaraju, S.; Sharma, A.; Antonova, A.U.; Sonowal, R.; Capaldo, C.; Powell, D.; Qayed, M.; et al. Indoles derived from intestinal microbiota act via type I interferon signaling to limit graft-versus-host disease. Blood 2018, 132, 2506-2519. [CrossRef] [PubMed]

300. Yu, J.; Luo, Y.; Zhu, Z.; Zhou, Y.; Sun, L.; Gao, J.; Sun, J.; Wang, G.; Yao, X.; Li, W. A tryptophan metabolite of the skin microbiota attenuates inflammation in patients with atopic dermatitis through the aryl hydrocarbon receptor. J. Allergy Clin. Immunol. 2019, 143, 2108-2119.e12. [CrossRef] [PubMed]

301. Bommarius, B.; Anyanful, A.; Izrayelit, Y.; Bhatt, S.; Cartwright, E.; Wang, W.; Swimm, A.I.; Benian, G.M.; Schroeder, F.C.; Kalman, D. A Family of Indoles Regulate Virulence and Shiga Toxin Production in Pathogenic E. coli. PLoS ONE 2013, 8, e54456. [CrossRef] [PubMed]

302. Romani, L.; Zelante, T.; De Luca, A.; Iannitti, R.G.; Moretti, S.; Bartoli, A.; Aversa, F.; Puccetti, P. Microbiota control of a tryptophan-AhR pathway in disease tolerance to fungi. Eur. J. Immunol. 2014, 44, 3192-3200. [CrossRef] [PubMed]

303. Cicenia, A.; Scirocco, A.; Carabotti, M.; Pallotta, L.; Marignani, M.; Severi, C. Postbiotic Activities of Lactobacilli-derived Factors. J. Clin. Gastroenterol. 2014, 48, S18-S22. [CrossRef]

304. Clayton, T.A.; Lindon, J.C.; Cloarec, O.; Antti, H.; Charuel, C.; Hanton, G.; Provost, J.P.; Le Net, J.L.; Baker, D.; Walley, R.J.; et al. Pharmaco-metabonomic phenotyping and personalized drug treatment. Nature 2006, 440, 1073-1077. [CrossRef]

305. Holmes, E.; Kinross, J.; Gibson, G.R.; Burcelin, R.; Jia, W.; Pettersson, S.; Nicholson, J.K. Therapeutic Modulation of Microbiota-Host Metabolic Interactions. Sci. Transl. Med. 2012, 4, 137rv6. [CrossRef]

306. Nicholson, J.K.; Holmes, E.; Kinross, J.; Burcelin, R.; Gibson, G.; Jia, W.; Pettersson, S. Host-gut microbiota metabolic interactions. Science 2012, 336, 1262-1267. [CrossRef] 